\title{
English teachers' perceptions of the middle school English language curriculum
}

\begin{tabular}{|c|c|c|}
\hline \multicolumn{3}{|c|}{$\begin{array}{l}{ }^{a} \text { Ağrı İbrahim Çeçen University, The Vocational School of Civil Aviation, Ağrı/Turkey } \\
{ }^{b} \text { Middle East Technical University, Faculty of Education, Ankara/Turkey }\end{array}$} \\
\hline \multicolumn{2}{|c|}{ Article Info } & Abstract \\
\hline \multicolumn{2}{|c|}{ DOI: $10.31704 /$ ijocis.2020.005 } & $\begin{array}{l}\text { In this study, which utilized survey as the research design, it was aimed to find } \\
\text { out the teachers' perceptions of the middle school English language }\end{array}$ \\
\hline \multicolumn{2}{|c|}{ Article History: } & curriculum which was developed in 2012 and revised in 2016. Target \\
\hline Received & 26 February 2020 & population of this study included all teachers working in Turkish public middle \\
\hline $\begin{array}{l}\text { Revised } \\
\text { Accepted }\end{array}$ & $\begin{array}{l}07 \text { May } 2020 \\
10 \text { Mav } 2020\end{array}$ & schools in Ankara, while the sample was composed of 349 teachers selected \\
\hline Online & 8 June 2020 & $\begin{array}{l}\text { through clustered sampling method. A questionnaire developed by the } \\
\text { researchers was used as data collection instrument. Findings revealed that }\end{array}$ \\
\hline \multicolumn{2}{|c|}{$\begin{array}{l}\text { Keywords: } \\
\text { Middle school English } \\
\text { curriculum, } \\
\text { teacher perceptions, } \\
\text { english teacher. }\end{array}$} & $\begin{array}{l}\text { many problems with respect to the components of the curriculum developed } \\
\text { in } 2012 \text { have been solved, while only a few but most crucial problems still } \\
\text { exist. It was concluded that this curriculum cannot develop students } \\
\text { autonomy, communicative competence, and their writing, listening, and } \\
\text { speaking skills. More research was suggested to be conducted to find out }\end{array}$ \\
\hline \multicolumn{2}{|c|}{$\begin{array}{l}\text { Article Type: } \\
\text { Research paper }\end{array}$} & $\begin{array}{l}\text { whether this failure resulted from the design itself or implementation } \\
\text { process. }\end{array}$ \\
\hline
\end{tabular}

\section{İngilizce öğretmenlerinin ortaokul İngilizce dersi öğretim programı ile ilgili} algıları

\begin{tabular}{|c|c|}
\hline \multicolumn{2}{|c|}{ Makale Bilgisi } \\
\hline \multicolumn{2}{|c|}{ DOI:10.31704/ijocis.2020.005 } \\
\hline \multicolumn{2}{|c|}{ Makale Geçmişi: } \\
\hline Geliş & 26 Şubat 2020 \\
\hline Düzeltme & 07 Mayıs 2020 \\
\hline Kabul & 10 Mayıs 2020 \\
\hline Çevrimiçi & 8 Haziran 2020 \\
\hline \multicolumn{2}{|c|}{$\begin{array}{l}\text { Anahtar Kelimeler: } \\
\text { Ortaokul İngilizce programı, } \\
\text { öğretmen algıları, } \\
\text { İngilizce öğretmeni. }\end{array}$} \\
\hline \multicolumn{2}{|c|}{ Makale Türü: } \\
\hline
\end{tabular}

\section{Öz}

Tarama yöntemi kullanılan bu çalışmada, öğretmenlerin 2012 yılında geliştirilip 2016'da revize edilen ortaokul İngilizce dersi öğretim programı ile ilgili algılarının belirlenmesi amaçlanmıştır. Çalışmanın evrenini Ankara'daki devlet ortaokullarında çalışan bütün İngilizce öğretmenleri oluştururken, örneklemi küme örnekleme yöntemi ile seçilen 349 öğretmenden oluşmaktadır. Araştırmacılar tarafından geliştirilen bir anket veri toplama aracı olarak kullanılmıştır. Bulgular, programın boyutları ile ilgili daha önceki birçok sorunun bu program ile çözüldüğünü, fakat halen birkaç çok önemli sorunun devam ettiğini göstermiştir. Öğrencilerin bağımsız çalışma, iletişimsel yeterlik, yazma, dinleme ve konuşma becerilerini geliştiremediği sonucuna varılmıştır. Bu başarısızlığın programın kendisinden mi yoksa uygulama biçiminden mi kaynaklandığını bulmak için daha fazla araştırma yapılması gerektiği önerilmiştir.

\footnotetext{
* Author: sukaya@agri.edu.tr

*** Author: as@metu.edu.tr
}

Orcid ID: 0000-0001-6593-3205

Orcid ID: 0000-0002-5941-4158 


\section{Introduction}

Foreign language education has been gaining more and more importance and attention due to the fast changes and improvements experienced all around the world. "The trend towards internationalization has increased the importance of being competent in communicating with people of different cultural backgrounds" (Fritz, Möllenberg \& Chen, 2002, p. 1). To this connection, there has been a growing focus on the teaching and learning of English in Turkey as well. When the close history of English language teaching policies of Turkey is examined, it is recognized that foreign language curriculum has been exposed to three curriculum reforms since 1997. The first one came into being in 1997, the second one followed in 2005, and third one was developed in 2012 and revised in 2016.

The curricular changes witnessed in 2012 resulted from Turkish education system's transition from the $8+4$ schooling model to the $4+4+4$ model. The first four, in this model, refer to primary education; the second four refer to middle school education and the third four refer to high school education period. The new system necessitated a new curriculum, because English instruction started to be provided from the 2 nd grade onward as different from the previous system according to which foreign language education was provided from the 4th grade onward. Another change stipulated by this system was that the 5 th graders who were accepted in the primary education in the past are in middle school education level now.

Any newly developed curriculum is put into practice due to the lacks and inefficiency of the previous curriculum, and the previous curriculum's inability to catch up with the changing and developing age and technology (Yaman, 2010). The middle school English language curriculum, which has been in implementation process since 2013, needs continuous evaluation in order to make it work better. To this connection, it was aimed to find out the teachers' perceptions of components of the middle school English language curriculum and the following research question and sub questions were formulated to find answers for this question:

1. What are the teachers' perceptions of the middle school English language curriculum?

1.1. What are the teachers' perceptions of the objectives of the middle school English language curriculum?

1.2. What are the teachers' perceptions of the content of the middle school English language curriculum?

1.3. What are the teachers' perceptions of the materials of the middle school English language curriculum?

1.4. What are the teachers' perceptions of the suggested activities of the middle school English language curriculum?

1.5. What are the teachers' perceptions of the suggested assessment methods and techniques of the middle school English language curriculum?

Aiming to analyze the teachers' perceptions of the middle school English language curriculum developed in 2012, the present study is significant in several ways as explained in the following paragraphs.

First and foremost, as curriculum development is a systematic process (Erdoğan, Kayır, Kaplan, AşıkÜnal \& Akpınar, 2015; Oliva, 1997; Ornstein \& Hunkins, 2004), the findings of the present study conducted on the curriculum are expected to contribute greatly to the curriculum development process and English language teaching policy in Turkey.

When the evaluation studies conducted on the components of the previous curricula are examined, it is seen that majority of them have focused on one grade level (Çelik, 2009; Demirtaş \& Erdem, 2015; Dinçer, 2013; Güneş, 2009; Ocak, Kızılkaya \& Boyraz, 2013; Yörü, 2012) or two (Büyükduman, 2005; Er, 2006; Erdoğan, 2005; Erkan, 2009; Koydemir, 2001; Mersinligil, 2002; Tekin-Özel, 2011; Yaman, 2010) 
in the same study, while only a few of them have focused on three grade levels (Ersen-Yanık, 2007; Harman, 1999; Örmeci, 2009). The present study is unique in that it is expected to obtain valuable and various data about the operation of the latest curriculum in four grade levels (5th, 6th, 7 th, and 8 th) in a single study. To this connection, it gives a more holistic perspective on this four-year curriculum.

\section{Method}

\section{Research Design}

The research design for this study is a survey which "gather[s] data at a particular point in time with the intention of describing the nature of existing conditions" (Cohen, Manion, \& Morrison, 2007, p. 205). Surveys "may vary in their levels of complexity from those that provide simple frequency counts to those that present relational analysis" (Cohen et al., 2007, p. 205). The survey in this study was used to describe the nature of existing conditions without any manipulation by providing frequency counts gathered. Another characteristic of the surveys is that they can "be differentiated in terms of their scope. A study of contemporary developments in post-secondary education, for example, might encompass the whole of western Europe; a study of subject choice, on the other hand, might be confined to one secondary school" (Cohen et al., 2007, p. 205). To this connection, this study is confined to the teachers working in a city, Ankara, and the findings of this study can be generalized to the perceptions of the teachers working in Ankara.

\section{Population and Sample}

The target population of this study was composed of all the teachers working in Turkish public schools in Ankara, while the participants of the study included teachers who were selected through cluster sampling method from 25 districts in Ankara. The population of the teachers teaching at the 5th, 6th, 7th and 8th grade levels in Ankara consisted of 1943 teachers according to the data obtained from MEIS module at www.mebbis.meb.gov.tr on 12.12.2016. Sample size is important for generalizability of the research (Gall, Gall, \& Borg, 2003). At least 100 participants are enough for descriptive studies and the researchers can reach as big sample as they can depending on the time and energy they have (Fraenkel, Hyun \& Wallen, 2012), the reliability of the research increases in this way as well (Cohen et al., 2007).

The sample size and all the other information are presented in Table 1. As cluster sampling method was used, all the teachers present in each school were invited to participate in the study, as a result in some districts more teachers participated than expected and they were included in the sample as presented in the table.

Table 1.

Distribution of the Teacher Population Across the Districts in Ankara

\begin{tabular}{lccc}
\hline Districts in Ankara & Population of Teachers in Districts & \% & Reached Sample Size \\
\hline Akyurt & 13 & .67 & 2 \\
Altındağ & 154 & 7.93 & 32 \\
Ayaş & 10 & .51 & 2 \\
Bala & 11 & .57 & 1 \\
Beypazarı & 18 & .93 & 3 \\
Çamlıdere & 2 & .10 & 0 \\
Çankaya & 257 & 13.23 & 43 \\
Çubuk & 32 & 1.65 & 8 \\
Elmadağ & 15 & .77 & 2 \\
Etimesgut & 193 & 9.93 & 38 \\
Evren & 1 & .05 & 0 \\
Gölbaşı & 57 & 2.93 & 10 \\
Güdül & 7 & .36 & 2 \\
\end{tabular}


Table 1 (Continuous)

\begin{tabular}{lccc}
\hline Haymana & 10 & .51 & 2 \\
Kalecik & 4 & .21 & 1 \\
Kazan & 28 & 1.44 & 4 \\
Keçiören & 325 & 16.73 & 55 \\
Kızılcahamam & 7 & .36 & 3 \\
Mamak & 223 & 11.48 & 40 \\
Nallıhan & 12 & .62 & 2 \\
Polatlı & 53 & 2.73 & 10 \\
Pursaklar & 55 & 2.83 & 11 \\
Sincan & 231 & 11.89 & 38 \\
Şereflikoçhisar & 13 & .67 & 3 \\
Yenimahalle & 212 & 10.91 & 37 \\
Sum & 1943 & 100.00 & 349 \\
\hline
\end{tabular}

\section{Teachers' Demographic Characteristics}

The demographic characteristics of the teachers are summarized in Table 2. As seen in the table, the sample was composed of 280 female (80.20\%) and 69 male participants (19.80\%). The participants' average age was found to be 36.5. Regarding education level, 326 teachers $(93.40 \%)$ had a bachelor's degree, 22 teachers (6.30\%) had Master's degree, and 1 teacher $(.30 \%)$ had a PhD degree. Regarding faculty type, 207 teachers (57.30\%) graduated from Faculty of Education, while 142 teachers $(42.70 \%)$ were graduates of other departments. To illustrate, 110 teachers $(31.50 \%)$ graduated from Faculty of Arts and Science, 17 teachers (6.30\%) graduated from Faculty of Language, History and Geography, and 15 teachers $(4.90 \%)$ graduated from some other faculties. Regarding type of department, 195 teachers $(55.90 \%)$ graduated from Foreign Language Education Department, 86 teachers $(24.70 \%)$ graduated from English Language and Literature Department, 16 teachers $(4.60 \%)$ graduated from Linguistics Department, 7 teachers $(2.00 \%)$ graduated from American Culture and Literature Department, 1 teacher (.30\%) graduated from Translation and Interpreting Department, and 44 teachers $(12.80 \%)$ graduated from other departments. With respect to exam participation, 340 teachers (97.40\%) haven't participated in TOEFL exam, while only 9 teachers $(2.60 \%)$ have participated in this exam. Likewise, of 349 teachers, 347 teachers (99.40\%) haven't participated in IELTS exam, while only 2 teachers (.60\%) have. Lastly, 150 teachers (43.00\%) haven't participated in YDS exam, while 199 teachers $(57.00 \%)$ have participated in this exam, and the average score of the YDS exam results was found to be 84.5 . Regarding the participants' experience in the profession, 76 teachers $(21.80 \%)$ had 1-5 years of experience, 92 teachers $(26.40 \%)$ had 6-10 years, the remaining 50 teachers $(14.30 \%)$ had 20 or more years of experience. The biggest proportion of the teachers had an experience of 6-10 years $(26.40 \%)$. Regarding experiences abroad, and participation in conferences in their area, 142 teachers $(40.70 \%)$ have been abroad, while 207 teachers $(59.3 \%)$ have never been abroad; and 190 teachers (54.4\%) have participated in conferences, while 159 teachers $(45.60 \%)$ have not. With respect to the grades that the participants taught, all teachers $(100 \%)$ taught in all grades including 5 th, 6 th, 7 th and 8th grade levels. Regarding participation in the in-service training about the curriculum developed in 2012, 143 teachers (41.00\%) have received in-service training, while 206 teachers $(59.00 \%)$ have not. Of 143 teachers who received in-service training $(41.00 \%), 13$ teachers $(9.00 \%)$ found the training satisfactory enough, 64 teachers $(44.80 \%)$ found the training partly satisfactory, while 66 teachers $(46.20 \%)$ found the training unsatisfactory. 206 teachers who did not receive any in-service training about the curriculum and 47 teachers who received in-service training learnt further about the curriculum in different ways. 
Table 2.

Demographic Characteristics of the Teachers Responding to the Questionnaire

\begin{tabular}{|c|c|c|c|c|}
\hline & Categories & $f$ & $\%$ & $\mathbf{M}$ \\
\hline \multirow[t]{2}{*}{ Gender } & Female & 280 & 80.20 & \\
\hline & Male & 69 & 19.80 & \\
\hline Age & & & & 36.50 \\
\hline \multirow[t]{3}{*}{ Education Level } & Bachelor & 326 & 93.40 & \\
\hline & Master's & 22 & 6.30 & \\
\hline & $\mathrm{PhD}$ & 1 & .30 & \\
\hline \multirow[t]{4}{*}{ Faculty } & Education & 207 & 57.30 & \\
\hline & Arts and Science & 110 & 31.50 & \\
\hline & Language, History and Geography & 17 & 6.30 & \\
\hline & Others & 15 & 4.90 & \\
\hline \multirow[t]{6}{*}{ Department } & Foreign Language Education & 195 & 55.90 & \\
\hline & English Language and Literature & 86 & 24.70 & \\
\hline & Linguistics & 16 & 4.60 & \\
\hline & American Culture and Literature & 7 & 2.00 & \\
\hline & Translation and Interpreting & 1 & .30 & \\
\hline & Others & 44 & 12.80 & \\
\hline \multirow[t]{2}{*}{ TOEFL Exam Participation } & Yes & 9 & 2.60 & \\
\hline & No & 340 & 97.40 & \\
\hline \multirow[t]{2}{*}{ IELTS Exam Participation } & Yes & 2 & .60 & \\
\hline & No & 347 & 99.40 & \\
\hline \multirow[t]{2}{*}{ YDS Participation } & Yes & 199 & 57.00 & \\
\hline & No & 150 & 43.00 & \\
\hline YDS Exam Results & & & & 84.50 \\
\hline \multirow[t]{5}{*}{ Experience } & 1-5 Years & 76 & 21.80 & \\
\hline & 6-10 Years & 92 & 26.40 & \\
\hline & $11-15$ Years & 75 & 21.50 & \\
\hline & $16-20$ Years & 56 & 16.00 & \\
\hline & More than 20 Years & 50 & 14.30 & \\
\hline \multirow[t]{2}{*}{ Studies or Being Abroad } & Yes & 142 & 40.70 & \\
\hline & No & 207 & 59.30 & \\
\hline \multirow[t]{2}{*}{ Conference Participation } & Yes & 190 & 54.40 & \\
\hline & No & 159 & 45.60 & \\
\hline \multirow[t]{4}{*}{ Grades Taught } & $5^{\text {th }}$ grades & 349 & 100.00 & \\
\hline & $6^{\text {th }}$ grades & 349 & 100.00 & \\
\hline & $7^{\text {th }}$ grades & 349 & 100.00 & \\
\hline & $8^{\text {th }}$ grades & 349 & 100.00 & \\
\hline \multirow[t]{2}{*}{ In-service participation } & Yes & 143 & 41.00 & \\
\hline & No & 206 & 59.00 & \\
\hline \multirow[t]{4}{*}{ Satisfaction of In-service } & Satisfied & 13 & 9.00 & \\
\hline & Partly & 64 & 44.80 & \\
\hline & Not Satisfied & 66 & 46.20 & \\
\hline & Total & 143 & 100.00 & \\
\hline \multirow[t]{5}{*}{ Knowledge Source of curriculum } & Personal search & 123 & 35.30 & \\
\hline & Colleague Meetings & 107 & 30.70 & \\
\hline & Both & 12 & 3.40 & \\
\hline & Others & 12 & 3.40 & \\
\hline & Total & 253 & & \\
\hline
\end{tabular}

\section{Data Collection Tools}

A questionnaire was used to collect data so as to answer the research question, which sought to examine teachers' perceptions of the middle school English language curriculum in terms of its theoretical soundness. In other words, it was aimed to find out whether the curriculum design was 
theoretically appropriate which refers to the merit of the curriculum. During development process, the latest curriculum developed by Ministry of National Education [MoNE] in 2012 and the related literature (Çelik, 2009; Er, 2006; Güneş, 2009; Mersinligil, 2002; Oliva, 1997; Ornstein \& Hunkins, 2004; Seçkin, 2010) were investigated in detail. 78 items from the related literature were collected in a pool, and then the appropriate ones were selected for the present study. 69 items were selected at the beginning and they were sent to experts in order to take their opinions for the questionnaire's content and face validity. Opinions were taken from three professors from Curriculum and Instruction Department and one professor from English Language Teaching Department. Based on feedback from these experts, necessary changes were applied to the questionnaire in terms of its shape and items. To illustrate, the first draft of the questionnaire was composed of 69 items, and some items were deleted or reworded by combining some items based on expert opinions. In addition, the format of the questionnaire was changed and some instructions were reworded based on these opinions. To illustrate, instead of writing the components of the curriculum and writing differing sentences, the name of the component was written followed by three dots to be completed with the items as will be seen in the tables. After expert opinions, the questionnaire was examined by five English teachers in order to find out whether the items in the questionnaire were understood as intended referring to face-related validity, which resulted in a negligible revision about wording of a few items. To illustrate, they had difficulty in understanding the meaning of "learner autonomy", so it was reworded to be understood easier.

Last of all, the questionnaire was administered to 65 teachers to check its reliability through Cronbach's alpha; however, 56 teachers returned the questionnaires. To this connection, the return rate was $86.00 \%$. The Cronbach's alpha values for the five subsections of the questionnaire were found to be $.95, .93, .91, .95$ and .91 for objectives, content, materials, activities, and assessment methods and techniques, respectively.

As a result of these procedures, the questionnaire was composed of two sections; the first section included items about teachers' demographic characteristics, and the second section had items about curriculum components which was expected to provide information about the teachers' perceptions of the curriculum. This second part of the questionnaire had five subsections and 56 items. The first subsection included 17 items about objectives, the second subsection covered 12 items about content, the third subsection consisted of six items about materials, the fourth subsection included 14 items about activities, and the final part covered seven items about assessment methods and techniques. The questionnaire was modelled on a five-point Likert scale, in which the teachers were asked to rate their level of agreement or disagreement by rating each item on this five-point scale such as 1- strongly disagree, 2- disagree, 3- neither agree nor disagree, 4- agree, and 5- strongly agree.

\section{Data Collection Process}

Before collection of data, necessary permissions were taken. First of all, data collection instruments were sent to the Human Research Ethical Committee (HREC) at Middle East Technical University, Ankara, Turkey, for review. After the permission was taken from HREC in 02.01.2017, official permission of Ankara Provincial National Education Directorate was applied to conduct the study. After approval of Ankara Provincial National Education Directorate obtained in 18.04.2017, data were collected for the main study as presented in the following paragraphs.

Data were collected by one of the researchers by visiting the selected schools. Upon the visit, the researcher introduced himself to all school administrators, and they were informed about the purpose of the study. Then, the approval from Ankara Provincial National Education Directorate was either shown to them or a copy of it was left for them. The teachers completed the questionnaire either while the researcher was there or they wanted the researcher to come back another day. To this connection, the researcher had to visit some schools two or even three times. Majority of the teachers could finish 
completing the questionnaire in the break time which lasted for 10 minutes, while some of them could not finish it in the break time and finished it in another break time.

\section{Data Analysis}

Data were analyzed through descriptive statistics procedures including means, frequencies and percentages. Depending on the data, either mean was used or frequencies and percentages were utilized to report the findings.

\section{Results}

Findings regarding the perceptions of English teachers about the components of the middle school English curriculum prepared for the 5th, 6th, 7th and 8th grades are presented under different subheadings in this section.

\section{Teachers' Perceptions of the Objectives of the Middle School English Language Curriculum}

The findings related to teachers' perceptions of the objectives of the curriculum are summarized in Table 3. The number and percentage of the participants who agreed or strongly agreed were summed up, likewise the number and percentage of the participants who disagreed or strongly disagreed were summed up while reporting the findings.

Table 3

Teachers' Perceptions of the Objectives of the Curriculum

\begin{tabular}{|c|c|c|c|c|c|c|c|c|c|c|}
\hline \multirow{2}{*}{ Objectives } & \multicolumn{2}{|c|}{ 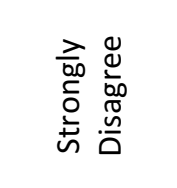 } & \multicolumn{2}{|c|}{ 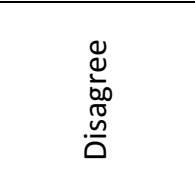 } & \multicolumn{2}{|c|}{ 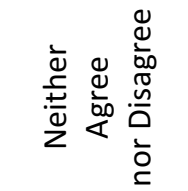 } & \multicolumn{2}{|r|}{ 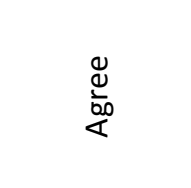 } & \multicolumn{2}{|c|}{ 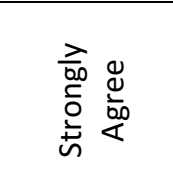 } \\
\hline & f & $\%$ & f & $\%$ & f & $\%$ & f & $\%$ & f & $\%$ \\
\hline $\begin{array}{l}\text {...are congruent with general purposes } \\
\text { of English language curriculum. }\end{array}$ & 14 & 4 & 58 & 16.60 & 88 & 25.20 & 163 & 46.70 & 26 & 7.40 \\
\hline ...are attainable. & 10 & 2.90 & 56 & 16.00 & 95 & 27.20 & 164 & 47.00 & 24 & 6.90 \\
\hline ...are observable and measurable. & 9 & 2.60 & 38 & 10.90 & 115 & 33.00 & 162 & 46.40 & 25 & 7.20 \\
\hline $\begin{array}{l}\text {...can be used in daily life by the } \\
\text { students. }\end{array}$ & 23 & 6.60 & 86 & 24.60 & 92 & 26.40 & 108 & 30.90 & 40 & 11.50 \\
\hline ...have a coherent arrangement. & 21 & 6.00 & 70 & 20.10 & 113 & 32.40 & 114 & 32.70 & 31 & 8.90 \\
\hline $\begin{array}{l}\text {...can be achieved in the planned time } \\
\text { of the units. }\end{array}$ & 24 & 6.90 & 72 & 20.60 & 64 & 18.30 & 144 & 41.30 & 45 & 12.90 \\
\hline $\begin{array}{l}\text {...can improve communicative } \\
\text { competence. }\end{array}$ & 29 & 8.30 & 107 & 30.70 & 123 & 35.20 & 77 & 22.10 & 12 & 3.40 \\
\hline ...can help develop learner autonomy. & 67 & 19.20 & 143 & 41.00 & 85 & 24.40 & 37 & 10.60 & 17 & 4.90 \\
\hline ...can help develop listening skills. & 39 & 11.20 & 99 & 28.40 & 98 & 28.10 & 99 & 28.40 & 14 & 4.00 \\
\hline $\begin{array}{l}\text {...are sufficient in quantity to develop } \\
\text { listening skills }\end{array}$ & 45 & 12.90 & 128 & 36.70 & 89 & 25.50 & 70 & 20.10 & 17 & 4.90 \\
\hline ...can help develop speaking skills. & 42 & 12 & 138 & 39.50 & 88 & 25.20 & 71 & 20.30 & 10 & 2.90 \\
\hline $\begin{array}{l}\text {... are sufficient in quantity to develop } \\
\text { speaking skills. }\end{array}$ & 54 & 15.5 & 134 & 38.40 & 105 & 30.10 & 41 & 11.70 & 15 & 4.30 \\
\hline ...can help develop writing skills. & 28 & 8.00 & 103 & 29.50 & 94 & 26.90 & 106 & 30.40 & 18 & 5.20 \\
\hline $\begin{array}{l}\text {...are sufficient in quantity to develop } \\
\text { writing skills }\end{array}$ & 39 & 11.2 & 109 & 31.20 & 101 & 28.90 & 83 & 23.80 & 17 & 4.90 \\
\hline ...can help develop reading skills. & 17 & 4.90 & 55 & 15.80 & 83 & 23.80 & 151 & 43.30 & 43 & 12.30 \\
\hline $\begin{array}{l}\text {... are sufficient in quantity to develop } \\
\text { reading skills }\end{array}$ & 18 & 5.20 & 66 & 18.90 & 87 & 24.90 & 130 & 37.20 & 48 & 13.80 \\
\hline $\begin{array}{l}\text {... are appropriate for students' level of } \\
\text { development. }\end{array}$ & 20 & 5.70 & 65 & 18.60 & 104 & 29.80 & 111 & 31.80 & 49 & 14.00 \\
\hline
\end{tabular}


Table 3 indicated that about $42.00 \%(n=147)$ to $56.00 \%(n=195)$ of the teachers agreed or strongly agreed that the objectives are congruent with the general purposes of English language curriculum (54.10\%), they are attainable (53.90\%), they are observable and measurable $(53.60 \%)$, they can be used by the students in their daily life $(42.40 \%)$, they have a coherent arrangement $(41.60 \%)$, they can be achieved in the planned time of the units $(54.20 \%)$, they can develop reading skills (55.60\%), they are sufficient in quantity to develop reading skills (51.00\%), and they are appropriate for students' level of development (45.80\%).

On the other hand, about $13.00 \%(n=45)$ to $31.00 \%(n=108)$ of the teachers disagreed or strongly disagreed on the mentioned aspects of the objectives, and about $18.00 \%(n=62)$ to $33.00 \%(n=115)$ of the teachers neither agreed nor disagreed on the mentioned aspects of the objectives.

Further examination of Table 3 indicated that about $38.00 \%(n=133)$ to $60.00 \%(n=209)$ of the teachers disagreed or strongly disagreed that the objectives can improve communicative competence (39.00\%), can develop learner autonomy (60.20\%), can develop listening skills (39.60\%), they are sufficient in quantity to develop listening skills (49.60\%), can develop speaking skills (51.50\%), are sufficient in quantity to develop speaking skills (53.90\%), can develop writing skills $(37.50 \%)$, are sufficient in quantity to develop writing skills $(42.40 \%)$.

On the other hand, about $15.00 \%(n=52)$ to $35.00 \%(n=122)$ of the teachers agreed or strongly agreed on the mentioned aspects of the objectives. Lastly, about $24.00 \%(n=84)$ to $35.00 \%(n=122)$ of the teachers neither agreed nor disagreed on the mentioned aspects of the objectives.

\section{Teachers' Perceptions of the Content of the Middle School English Language Curriculum}

The findings related to teachers' perceptions of the content of the curriculum are summarized in Table 4.

Table 4

Teachers' Perceptions of the Content of the Curriculum

\begin{tabular}{|c|c|c|c|c|c|c|c|c|c|c|}
\hline \multirow[t]{2}{*}{ Content } & \multicolumn{3}{|c|}{ 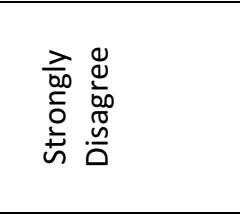 } & 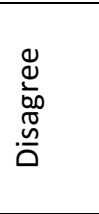 & \multicolumn{2}{|c|}{ 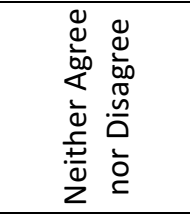 } & \multicolumn{2}{|r|}{$\underset{\frac{1}{20}}{\frac{0}{<}}$} & \multicolumn{2}{|c|}{ 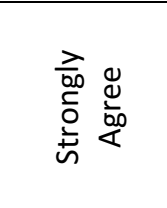 } \\
\hline & $f$ & $\%$ & $f$ & $\%$ & $f$ & $\%$ & $f$ & $\%$ & $f$ & $\%$ \\
\hline ...is coherent with the objectives. & 9 & 2.60 & 36 & 10.30 & 97 & 27.80 & 168 & 48.10 & 39 & 11.20 \\
\hline $\begin{array}{l}\text {...is appropriate for students' needs } \\
\text { and interests. }\end{array}$ & 19 & 5.40 & 82 & 23.50 & 110 & 31.50 & 98 & 28.10 & 40 & 11.50 \\
\hline $\begin{array}{l}\text {...is appropriate for students' level of } \\
\text { development. }\end{array}$ & 14 & 4.00 & 59 & 16.90 & 112 & 32.10 & 123 & 35.20 & 41 & 11.70 \\
\hline $\begin{array}{l}\text {...can ensure active participation of } \\
\text { the } \\
\text { students. }\end{array}$ & 21 & 6.00 & 69 & 19.80 & 124 & 35.50 & 107 & 30.70 & 27 & 7.70 \\
\hline $\begin{array}{l}\text {...can ensure attainment of the } \\
\text { objectives. }\end{array}$ & 14 & 4.00 & 48 & 13.80 & 130 & 37.20 & 128 & 36.70 & 29 & 8.30 \\
\hline $\begin{array}{l}\text {...contains information that students } \\
\text { can use in their daily life. }\end{array}$ & 14 & 4.00 & 66 & 18.90 & 107 & 30.70 & 134 & 38.40 & 28 & 8.00 \\
\hline ...is coherent in itself. & 14 & 4.00 & 44 & 12.60 & 115 & 33.00 & 151 & 43.30 & 25 & 7.20 \\
\hline ...can help develop writing skills. & 21 & 6.00 & 93 & 26.60 & 108 & 30.90 & 114 & 32.70 & 13 & 3.70 \\
\hline ...can help develop reading skills. & 8 & 2.30 & 68 & 19.50 & 91 & 26.10 & 154 & 44.10 & 28 & 8.00 \\
\hline ...can help develop listening skills. & 19 & 5.40 & 112 & 32.10 & 103 & 29.50 & 98 & 28.10 & 17 & 4.90 \\
\hline ...can help develop speaking skills. & 26 & 7.40 & 134 & 38.40 & 97 & 27.80 & 78 & 22.30 & 14 & 4.00 \\
\hline ...can be finished in the planned time. & 31 & 8.90 & 69 & 19.80 & 80 & 22.90 & 136 & 39.00 & 33 & 9.50 \\
\hline
\end{tabular}

As seen in the table, about $37.00 \%(n=147)$ to $59.00 \%(n=195)$ of the teachers agreed or strongly agreed that the content is coherent with the objectives (59.30\%), appropriate for students' needs and 
interests (39.60\%), appropriate for students' level of development $(46.90 \%)$, can ensure active participation of the students (38.40), can ensure the achievement of the objectives (45.00\%), contains information that students can use in their life $(46.40 \%)$, coherent in itself $(50.50 \%)$, can help develop reading skills $(52.10 \%)$, and it can be finished in the planned time $(48.50 \%)$. On the other hand, about $16.00 \%(n=56)$ to $29.00 \%(n=101)$ of the teachers disagreed or strongly disagreed on the mentioned aspects of the content, and about $23.00 \%(n=80)$ to $37.00 \%(n=129)$ of the teachers neither agreed nor disagreed on the above mentioned aspects of the content.

In addition, about $33.00 \%(n=115)$ to $38.00 \%(n=133)$ of the teachers disagreed or strongly disagreed with some of the characteristics of the curriculum content. To illustrate, the participants reported that the content cannot help develop writing skills $(32.60 \%)$, cannot help develop listening skills $(37.50 \%)$, and cannot help develop speaking skills (35.80\%). On the other hand, about $26.00 \%$ $(n=91)$ to $36.00 \%(n=126)$ of the teachers agreed or strongly agreed on the mentioned aspects of the content, and about $26.00 \%(n=91)$ to $30.00 \%(n=105)$ of the teachers neither agreed nor disagreed on the above mentioned aspects of the content.

\section{Teachers' Perceptions of the Materials Suggested in the Curriculum}

The findings related to the teachers' perceptions of the materials of the curriculum are summarized in Table 5.

Table 5

Teachers' Perceptions of the Materials Suggested in the Curriculum

\begin{tabular}{|c|c|c|c|c|c|c|c|c|c|c|}
\hline \multirow[t]{2}{*}{ Materials } & \multicolumn{2}{|c|}{ 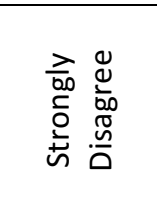 } & \multicolumn{2}{|c|}{ 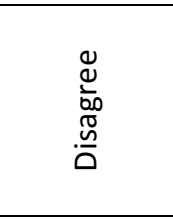 } & \multicolumn{2}{|c|}{ 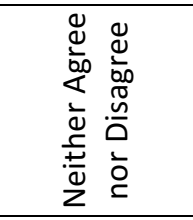 } & \multicolumn{2}{|c|}{ 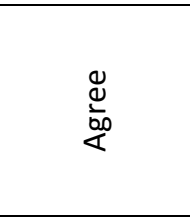 } & \multicolumn{2}{|c|}{ 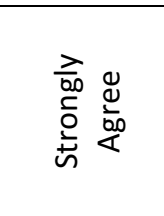 } \\
\hline & $f$ & $\%$ & $f$ & $\%$ & $f$ & $\%$ & $f$ & $\%$ & $f$ & $\%$ \\
\hline $\begin{array}{l}\text {...can support the attainment of the } \\
\text { objectives. }\end{array}$ & 20 & 5.70 & 85 & 24.40 & 96 & 27.50 & 113 & 32.40 & 35 & 10.0 \\
\hline $\begin{array}{l}\text {...can increase active participation of the } \\
\text { students. }\end{array}$ & 20 & 5.70 & 83 & 23.80 & 110 & 31.50 & 108 & 30.90 & 28 & 8.00 \\
\hline $\begin{array}{l}\text {...can increase students' interest in the } \\
\text { lesson. }\end{array}$ & 22 & 6.30 & 88 & 25.20 & 118 & 33.80 & 94 & 26.90 & 27 & 7.70 \\
\hline ...can be reached easily. & 17 & 4.90 & 62 & 17.80 & 89 & 25.50 & 146 & 41.80 & 35 & 10.00 \\
\hline ...can consolidate students' learning. & 19 & 5.40 & 67 & 19.20 & 111 & 31.80 & 123 & 35.20 & 29 & 8.30 \\
\hline ....are appropriate for students' age level. & 15 & 4.30 & 52 & 14.90 & 93 & 26.60 & 139 & 39.80 & 50 & 14.30 \\
\hline
\end{tabular}

As seen in the table, about $35.00 \%(n=122)$ to $54.00 \%(n=189)$ of the teachers agreed or strongly agreed that the materials can support the attainment of the objectives $(42.40 \%)$, can increase active participation of the students (38.90\%), can increase students' interest in the lesson (34.60\%), can be reached easily ( $51.80 \%)$, can consolidate students' learning (43.50\%), and are appropriate for students' age level (54.10\%). On the other hand, about 19.00\% $(n=66)$ to $31.00 \%(n=108)$ of the teachers disagreed or strongly disagreed on the mentioned aspects of the materials, and about $25.00 \%(n=87)$ to $34.00 \%(n=118)$ of the teachers neither agreed nor disagreed on the mentioned aspects of the materials.

\section{Teachers' Perceptions of the Activities Suggested in the Curriculum}

The findings related to teachers' perceptions of the activities suggested in the curriculum are presented in Table 6. As seen in the table, about $36.00 \%(n=126)$ to $51.00 \%(n=178)$ of the teachers agreed or strongly agreed that the activities can help students develop positive attitudes towards English (36.10\%), can increase active participation of the students $(37.60 \%)$, they can ensure the attainment of the objectives (45.20\%), are appropriate for students' level of development $(48.90 \%)$, are in parallel to students' life (46.40\%), can develop students' reading skills $(50.70 \%)$, are applicable 
in the class (49.90\%), and they are student-centered (49.30\%). On the other hand, about $20.00 \%(n=69)$ to $29.00 \%$ ( $n=101$ ) of the teachers disagreed or strongly disagreed on the mentioned characteristics of the activities, and about $27.00 \%(n=94)$ to $36.00 \%(n=125)$ of the teachers neither agreed nor disagreed on the mentioned aspects of the activities.

Table 6

Teachers' Perceptions of the Activities Suggested in the Curriculum

\begin{tabular}{|c|c|c|c|c|c|c|c|c|c|c|}
\hline \multirow[t]{2}{*}{ Activities... } & \multicolumn{2}{|c|}{ 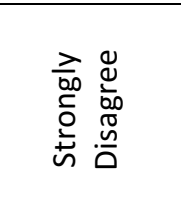 } & \multicolumn{2}{|r|}{$\frac{\Phi}{\frac{1}{60}}$} & \multicolumn{2}{|c|}{ 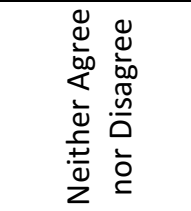 } & \multicolumn{2}{|c|}{ 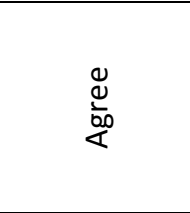 } & \multicolumn{2}{|c|}{ 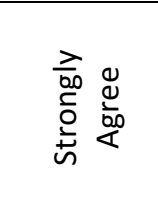 } \\
\hline & $f$ & $\%$ & $f$ & $\%$ & f & $\%$ & $f$ & $\%$ & $f$ & $\%$ \\
\hline $\begin{array}{l}\text {...can help students develop positive } \\
\text { attitudes towards English. }\end{array}$ & 17 & 4.90 & 84 & 24.10 & 122 & 35.00 & 107 & 30.70 & 19 & 5.40 \\
\hline $\begin{array}{l}\text { the } \\
\text { students. }\end{array}$ & 18 & 5.20 & 73 & 20.90 & 127 & 36.40 & 107 & 30.70 & 24 & 6.90 \\
\hline $\begin{array}{l}\text {...can ensure the attainment of the } \\
\text { objectives. }\end{array}$ & 14 & 4.00 & 60 & 17.20 & 117 & 33.50 & 131 & 37.50 & 27 & 7.70 \\
\hline $\begin{array}{l}\text {...are appropriate for students' level of } \\
\text { development. }\end{array}$ & 9 & 2.60 & 67 & 19.20 & 102 & 29.20 & 128 & 36.70 & 43 & 12.20 \\
\hline ...are in parallel to students' daily life. & 13 & 3.70 & 72 & 20.60 & 102 & 29.20 & 125 & 35.80 & 37 & 10.60 \\
\hline $\begin{array}{l}\text {...can develop communicative } \\
\text { competence. }\end{array}$ & 22 & 6.30 & 112 & 32.10 & 112 & 32.10 & 88 & 25.20 & 15 & 4.30 \\
\hline ...can develop students' listening skills. & 26 & 7.40 & 104 & 29.80 & 103 & 29.50 & 99 & 28.40 & 17 & 4.90 \\
\hline ...can develop students' reading skills. & 13 & 3.70 & 67 & 19.20 & 92 & 26.40 & 148 & 42.40 & 29 & 8.30 \\
\hline ...can develop students' writing skills. & 25 & 7.20 & 101 & 28.90 & 99 & 28.40 & 107 & 30.70 & 17 & 4.90 \\
\hline $\begin{array}{l}\text {...can develop students' speaking } \\
\text { skills. }\end{array}$ & 34 & 9.70 & 116 & 33.20 & 97 & 27.80 & 85 & 24.40 & 17 & 4.90 \\
\hline ...are applicable. & 13 & 3.70 & 58 & 16.60 & 104 & 29.80 & 149 & 42.70 & 25 & 7.20 \\
\hline ....are student-centered & 14 & 4.00 & 68 & 19.50 & 95 & 27.20 & 133 & 38.10 & 39 & 11.20 \\
\hline ...can develop learner autonomy. & 27 & 7.70 & 113 & 32.40 & 126 & 36.10 & 69 & 19.80 & 14 & 4.00 \\
\hline $\begin{array}{l}\text {...are appropriate for students' } \\
\text { individual differences. }\end{array}$ & 60 & 17.00 & 126 & 36.30 & 107 & 30.70 & 51 & 14.60 & 5 & 1.40 \\
\hline
\end{tabular}

What is to add, about $36.00 \%(n=126)$ to $53.00 \%(n=185)$ of the teachers disagreed or strongly disagreed on six characteristics of the suggested activities. These findings indicated that the activities cannot develop communicative competence (38.40\%), cannot develop students' listening skills (37.20\%), cannot develop students' writing skills (36.10\%), cannot develop students' speaking skills (42.90\%), cannot develop learner autonomy $(40.10 \%)$, and they are not appropriate for the students' individual differences (53.30\%). On the other hand, Table 6 indicated that about $16.00 \%(n=55)$ to $35.00 \%(n=122)$ of the teachers agreed or strongly agreed on the mentioned aspects of the activities. What is to add, about $26.00 \%(n=91)$ to $36.00 \%(n=125)$ of the teachers neither agreed nor disagreed on the above-mentioned aspects of the activities.

\section{Teachers' Perceptions of the Assessment Methods and Techniques of the Middle School English Language Curriculum}

The findings related to teachers' perceptions of the assessment methods and techniques suggested in the curriculum are summarized in Table 7 . As seen in the table, about $40.00 \%$ ( $n=140)$ to $60.00 \%$ $(n=209)$ of the teachers agreed or strongly agreed that the suggested assessment methods and techniques are applicable (53.30\%), are congruent with the objectives $(60.20 \%)$, take students' level of development into account (45.60\%), can measure students' reading skills $(52.00 \%)$, and they can measure students' writing skills (39.60\%). On the other hand, about $15.00 \%(n=52)$ to $31.00 \%(n=108)$ of the teachers disagreed or strongly disagreed on the mentioned aspects of the suggested assessment 
methods and techniques, and about $24.00 \%(n=84)$ to $31.00 \%(n=108)$ of the teachers neither agreed nor disagreed on the above mentioned characteristics of the suggested assessment methods and techniques.

Table 7

Teachers' Perceptions of the Assessment Methods and Techniques Suggested in the Curriculum

\begin{tabular}{|c|c|c|c|c|c|c|c|c|c|c|}
\hline \multirow{2}{*}{$\begin{array}{l}\text { Assessment } \\
\text { techniques }\end{array}$} & \multicolumn{2}{|c|}{ 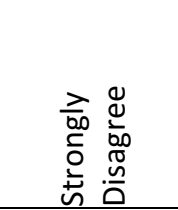 } & \multicolumn{2}{|c|}{$\begin{array}{l}0 \\
\frac{1}{20} \\
\frac{\mathscr{N}}{0} \\
\frac{\mathscr{n}}{0}\end{array}$} & \multicolumn{2}{|c|}{ 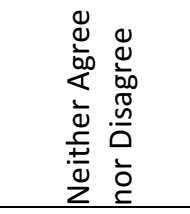 } & \multicolumn{2}{|c|}{$\underset{\frac{1}{20}}{\frac{0}{4}}$} & \multicolumn{2}{|c|}{ 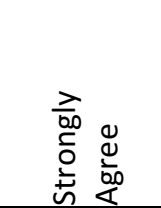 } \\
\hline & $\mathbf{f}$ & $\%$ & $f$ & $\%$ & f & $\%$ & $f$ & $\%$ & $f$ & $\%$ \\
\hline ...are applicable. & 13 & 3.70 & 52 & 14.90 & 98 & 28.10 & 163 & 46.70 & 23 & 6.60 \\
\hline ...are congruent with objectives. & 7 & 2.00 & 48 & 13.80 & 84 & 24.10 & 177 & 50.70 & 33 & 9.50 \\
\hline $\begin{array}{l}\text {...take students' level of } \\
\text { development } \\
\text { into account. }\end{array}$ & 9 & 2.60 & 71 & 20.30 & 110 & 31.50 & 134 & 38.40 & 25 & 7.20 \\
\hline $\begin{array}{l}\text {...can measure students' listening } \\
\text { skills. }\end{array}$ & 26 & 7.40 & 111 & 31.80 & 108 & 30.90 & 87 & 24.90 & 17 & 4.90 \\
\hline $\begin{array}{l}\text {...can measure students' reading } \\
\text { skills. }\end{array}$ & 12 & 3.40 & 59 & 16.90 & 97 & 27.80 & 141 & 40.50 & 40 & 11.50 \\
\hline $\begin{array}{l}\text {...can measure students' speaking } \\
\text { skills. }\end{array}$ & 37 & 10.60 & 107 & 30.70 & 115 & 33.00 & 72 & 20.60 & 18 & 5.20 \\
\hline $\begin{array}{l}\text {...can measure students' writing } \\
\text { skills. }\end{array}$ & 28 & 8.00 & 83 & 23.80 & 100 & 28.70 & 121 & 34.70 & 17 & 4.90 \\
\hline
\end{tabular}

In addition, about $36.00 \%(n=126)$ to $53.00 \%(n=185)$ of the teachers disagreed or strongly disagreed with the items which state that the suggested assessment methods and techniques can measure listening skills (39.20\%), and can measure students' speaking skills $(41.30 \%)$. On the other hand, about $25.00 \%(n=87)$ to $29.00 \%(n=101)$ of the teachers agreed or strongly agreed on the mentioned characteristics of the suggested assessment methods and techniques, and about $30.00 \%$ $(n=104)$ to $33.00 \%(n=115)$ of the teachers neither agreed nor disagreed on the mentioned aspects of the suggested assessment methods and techniques.

\section{Discussion, Conclusion and Implications}

The research question was asked to find out the perceptions of English language teachers about the middle school English language curriculum. A questionnaire composed of two parts was used to answer this research question. The first part included items about teachers' demographic characteristics, and the second part was composed of items about curriculum components.

To start with the results related to the demographic characteristics of the participants, there were more female than male participants, almost all of the teachers had a bachelor's degree, about threefifth of them graduated from foreign language education department, about three-fifth of them participated in YDS exam, but there was almost no participation in TOEFL and IELTS; two-fifth of them have been abroad; more than three-fifth of them did not follow any publication about their profession; the participation in conference about their profession was almost equal, and all of them were teaching in 4 grade levels. Regarding their source of knowledge about the middle school English language curriculum, only two-fifth of them have participated in in-service training, and among those who participated, only one-tenth of them found the in-service training satisfactory enough, so they mainly learnt about the curriculum in colleague meetings or through personal search. 
As the demographic characteristics showed most of the teachers were graduates of foreign language department as expected. However, their participation in exams showed that they are good at reading comprehension which is measured by YDS exam, while their proficiency in listening, speaking, and writing skills is not known as almost none of them have participated in TOEFL and IELTS. The other important point is that the teachers did not develop themselves in parallel to the recent developments in this area. Similar to the results found by Yaman (2010) and Tekin-Özel (2011), this result indicated that the majority of the teachers have not participated in any in-service training about the middle school English language curriculum, so their knowledge about the curriculum was limited to their personal search and the colleague meetings. Therefore, it can be put forward that the curriculum developed in 2012 cannot be expected to cause any change in teachers' way of implementation.

When the findings about the teachers' perceptions of the components of the curriculum are examined, it is seen that they have both negative and positive perceptions of the curriculum components. To start with their positive perceptions of the objectives, as suggested in the study of Güneş (2009), the objectives were found to be congruent with the general purposes of English language curriculum in the present study. Consistent with the studies of $\operatorname{Er}$ (2006), and Güneş (2009), they were reported to be consistent with each other. In contrast to the studies conducted by Örmeci (2009), Tekin-Özel (2011), and Yaman (2010) which indicated that the objectives were above students' level, the present study and the studies conducted by Büyükduman (2005) and Güneş (2009) showed that they were appropriate for the students' level of development. Furthermore, they were found to be attainable, observable and measurable, helpful in developing students' reading skills, and sufficient in quantity to develop the students' reading skills.

On the other hand, as the studies conducted by Örmeci (2009) and Tekin-Özel (2011) suggested, the findings of the present study indicated that this curriculum cannot develop learner autonomy. In addition, it was found that the objectives cannot develop students' communicative competence. The findings also indicated that the objectives were not very helpful in developing the students' listening, speaking, and writing skills, and they were found to be insufficient in quantity to develop those skills. This finding is consistent with the studies of Büyükduman (2005), Güneş (2009), Yaman (2010), and Yörü (2012) which concluded that objectives related to reading skills were attainable, while the ones related to listening, writing and speaking skills were not possible to be attained.

The findings related to the content of the curriculum indicated that the teachers had more positive perceptions than the negative ones. To illustrate, in contrast to Büyükduman (2005) who found that the content was not consistent with the objectives, the present study reported the opposite consistent with the studies conducted by $\operatorname{Er}$ (2006), Güneş (2009), and Mersinligil (2002). Consistent with the studies of Er (2006) and Güneş (2009), the present study showed that the content was appropriate for the needs and interests of the students. As suggested in the studies of Güneş (2009), and Mersinligil (2002), the content was found to be appropriate for the students' level of development in the present study which is in direct contrast to the study conducted by Harman (1999). Consistent with the study of Güneş (2009), the content was found to be coherent in itself, and it included information that students could use in their daily life. In contrast to the studies conducted by Büyükduman (2005), Demirtaş and Erdem (2015), Dinçer (2013), Er (2006), Erdoğan (2005), Erkan (2009), Mersinligil (2002), Ocak, Kızılkaya, and Boyraz (2013), Örmeci (2009), Tekin-Özel (2011), Yaman (2010), and Yörü (2012), which concluded that the time allocated for the implementation of the curriculum was inadequate, this study signified that the content can be finished in the planned time. Some of these results of the 
present study are in direct contrast to the study conducted by Harman (1999) who found that the content could not be applied in real life, and it was not appropriate for students' age and level. What is more, it was found that the content can ensure active participation of the students, ensure the achievement of the objectives, and develop the students' reading skills. On the other hand, like the findings with respect to the objectives, it was found out that the content cannot develop the students' listening, speaking, and writing skills.

The results with respect to the materials of the curriculum showed that the teachers had positive perceptions of the materials. To illustrate, the results indicated that the suggested materials could support the attainment of the objectives, increase active participation of the students, increase the students' interest in the lesson, be reached easily as found by Güneş (2009). They were also reported to be appropriate for students' age level in the present study as suggested in the study of Güneş (2009). To this connection, it can be put forward that there are no problems with the suggested materials.

The results regarding the activities suggested in the curriculum indicated more positive characteristics than the negative ones. To begin with the positive aspects, the results indicated that the activities can help the students develop positive attitudes towards English, increase active participation of the students as suggested in the study of Güneş (2009). Inconsistent with the study of $\operatorname{Er}(2006)$ which concluded that the activities were not consistent with objectives, they were found to ensure the attainment of the objectives in the present study. In contrast to the study of Erkan (2009), the present study signified that the activities were applicable in the classroom consistent with the study of Güneş (2009). As reported in the studies conducted by Büyükduman (2005) and Güneş (2009), they were found to be student-centered in the present study. What is to add, they were found to be appropriate for the students' level of development, in parallel to the students' daily life. In contrast to these positive characteristics, the results also indicated that the activities cannot develop the students' communicative competence, listening, speaking and writing skills, while only students' reading skills can be developed.

Lastly, the results related to teachers' perceptions of the assessment methods and techniques suggested in the curriculum indicated that they are applicable, and congruent with the objectives as suggested in the study of Güneş (2009). In addition, the results revealed that they take the students' level of development into account, and they can be used to measure the students' reading and writing skills. On the other hand, it was found that the suggested assessment methods and techniques cannot be used to measure the students' listening and speaking skills.

Compared the evaluation studies conducted on English language curricula up to now, the findings of the present study indicated that many problems with respect to the components of the curriculum developed in 2012 have been solved, while only a few but most crucial problems still existed. The most important problem in this respect is that like the other curricula developed since 1997, this curriculum cannot develop students' autonomy, communicative competence, and their writing, listening, and speaking skills. Although this curriculum has been designed to develop learners' communicative competence (MoNE, 2013) either through writing or speaking, these findings revealed that this curriculum cannot develop learners' writing, listening, and speaking skills. To these connections, more research is needed to examine the reasons behind this failure in order to find out whether the failure results from the curriculum itself or the implementation of the curriculum which can be influenced by many variables. In addition, this study can be replicated in other cities of Turkey so as to compare the findings. 


\section{Acknowledgement}

This study was produced from the corresponding author's PhD Dissertation titled 'Evaluation of middle school English language curriculum developed in 2012 utilizing Stake's countenance evaluation model' submitted to Middle East Technical University.

A part of this study was also presented as oral presentation in the 6th International Conference on Curriculum and Instruction, 11-13 October, 2018, Kars, Turkey. 


\section{TÜRKÇE SÜRÜM}

\section{Giriş}

Tüm dünyada yaşanan hızlı değişiklikler ve iyileştirmelerin de etkisiyle yabancı dil eğitimi giderek daha fazla önem ve dikkat çekmektedir. "Uluslararasılaşma eğilimi, farklı kültürel geçmişlere sahip insanlarla iletişim kurma konusunda yetkin olmanın önemini artırmıştır" (Fritz, Möllenberg \& Chen, 2002 , p. 1). Bu bağlamda, Türkiye'de de İngilizce öğretimi ve öğrenimi üzerinde giderek daha fazla durulmaktadır. Türkiye'nin İngilizce öğretim politikalarının yakın tarihi incelendiğinde, 1997 yılından bu yana yabancı dil öğretim programının 3 öğretim programı reformuna maruz kaldığı kabul edilmektedir. Birincisi 1997'de, ikincisi 2005'te, üçüncüsü 2012'de geliştirilmiş ve 2016'da revize edilmiştir.

2012 yılında yaşanan öğretim programı değişiklikleri Türk eğitim sisteminin $8+4$ eğitim modelinden $4+4+4$ modeline geçişinden kaynaklanmıştır. Bu modeldeki ilk dört yıl ilkokul eğitimini; ikinci dördü ortaokul eğitimini, son dördü ise lise eğitim dönemini ifade eder. Yeni sistem yeni bir öğretim programı gerektirdi, çünkü 4. sınıftan itibaren verildiği önceki sistemden farklı olarak İngilizce eğitimi 2. sınıftan itibaren verilmeye başlandı. Bu sistem tarafından öngörülen bir başka değişiklik de, geçmişte ilköğretimde kabul edilen 5. sınıf öğrencilerinin şimdi ortaokul eğitimi düzeyinde olmasıydı.

Yeni geliştirilen herhangi bir öğretim programı, önceki öğretim programının yetersizliği ve verimsizliği, ve önceki öğretim programının değişen ve gelişen dönem ve teknolojiyi yakalayamaması nedeniyle uygulamaya konulur (Yaman, 2010). Bu nedenle, yeni bir öğretim programı olarak, 2013'ten bu yana uygulama sürecinde olan ortaokul İngilizce öğretim programı, daha iyi çalışması için sürekli değerlendirmeye intiyaç duymaktadır. Bu bağlamda, öğretmenlerin ortaokul İngilizce dersi öğretim programının bileşenleri hakkındaki algılarının belirlenmesi amaçlanmıştır ve bu soruya cevap bulmak için aşağıdaki araştırma sorusu ve alt sorular formüle edilmiştir:

1. Öğretmenlerin ortaokul İngilizce dersi öğretim programına ilişkin algıları nelerdir?

1.1. Öğretmenlerin ortaokul İngilizce dersi öğretim programının hedefleri hakkındaki algıları nelerdir?

1.2. Öğretmenlerin ortaokul İngilizce dersi öğretim programının içeriği hakkındaki algıları nelerdir?

1.3. Öğretmenlerin ortaokul İngilizce dersi öğretim programının araç-gereçleri hakkındaki algıları nelerdir?

1.4. Öğretmenlerin ortaokul İngilizce dersi öğretim programının etkinlikleri hakkındaki algıları nelerdir?

1.5. Öğretmenlerin ortaokul İngilizce dersi öğretim programının değerlendirme yöntem ve teknikleri hakkındaki algıları nelerdir?

2012 yılında geliştirilen ortaokul İngilizce öğretim programını değerlendirmeyi amaçlayan bu çalışma, aşağıdaki paragraflarda açıklandığı gibi çeşitli yönleriyle önemlidir.

Her şeyden önce, program geliştirme sistematik bir süreç olduğundan (Erdoğan, Kayır, Kaplan, AşıkÜnal \& Akpınar, 2015; Oliva, 1997; Ornstein \& Hunkins, 2004), öğretim programı üzerine yapılan bu çalışmanın bulgularının Türkiye'deki program geliştirme sürecine ve İngilizce dersi öğretimi politikasına büyük katkı sağlaması beklenmektedir.

Önceki öğretim programlarının bileşenleri üzerinde yapılan değerlendirme çalışmaları incelendiğinde, çoğunluğunun bir (Çelik, 2009; Demirtaş \& Erdem, 2015; Dinçer, 2013; Güneş, 2009; Ocak, Kızılkaya \& Boyraz, 2013; Yörü, 2012) veya iki sınıf düzeyine (Büyükduman, 2005; Er, 2006; Erdoğan, 2005; Erkan, 2009; Koydemir, 2001; Mersinligil, 2002; Tekin-Özel, 2011; Yaman, 2010) odaklandığı görülmekte iken aynı çalışmada üç sınıf seviyesine odaklanan çalışmalar (Ersen-Yanık, 2007; Harman, 1999; Örmeci, 2009) az sayıdadır. Bu çalışmada, tek bir çalışmada en son öğretim programının dört sınıf düzeyi (5., 6., 7. ve 8.) hakkında değerli ve çeşitli veriler elde edilmesi beklendiği 
için çalışma önemlidir. Bu bağlamda, çalışma bu dört yıllık öğretim programına daha bütünsel bir bakış açısı kazandırmaktadır.

\section{Yöntem}

\section{Araştırma Deseni}

Bu çalışma için "mevcut koşulların doğasını tanımlamak amacıyla belirli bir noktada veri toplamaya" (Cohen, Manion \& Morrison, 2007, p. 205) imkan sağlayan tarama yöntemi kullanılmıştır. Tarama modelleri "karmaşıklık düzeylerinde ilişkisel analiz sunanlar ile basit sıklık sayımları sağlayanlar bakımından farklııık gösterebilir" (Cohen et al., 2007, p. 205). Bu araştırmada, toplanan veriler herhangi bir değişiklik yapılmaksızın mevcut koşulların doğası tanımlamak için kullanılmıştır. Tarama yönteminin bir başka özelliği de "kapsamları açısından farklılaştırılabilmeleridir. Örneğin, orta öğretim sonrası eğitimdeki çağdaş gelişmelerin incelenmesi, tüm Batı Avrupa'yı kapsayabilir; diğer yandan, konu seçimi çalışması bir ortaokulla sınırlı olabilir "(Cohen et al., 2007, p. 205). Bu bağlamda, bu çalışma Ankara ilinde çalışan öğretmenlerle sınırlıdır ve bu araştırmanın bulguları Ankara'da çalışan öğretmenlerin algılarına genellenebilir.

\section{Evren ve Örneklem}

Tablo 1

Ankara'daki Öğretmen Evreninin Illçelere Dağııımı

\begin{tabular}{|c|c|c|c|}
\hline Ankara'daki İlçeler & $\begin{array}{c}\text { İlçelerdeki } \\
\text { Öğretmen Evreni }\end{array}$ & $\%$ & $\begin{array}{c}\text { Ulaşılan Örneklem } \\
\text { Büyüklüğü }\end{array}$ \\
\hline Akyurt & 13 & .67 & 2 \\
\hline Altındağ & 154 & 7.93 & 32 \\
\hline Ayaş & 10 & .51 & 2 \\
\hline Bala & 11 & .57 & 1 \\
\hline Beypazarı & 18 & .93 & 3 \\
\hline Çamlıdere & 2 & .10 & 0 \\
\hline Çankaya & 257 & 13.23 & 43 \\
\hline Çubuk & 32 & 1.65 & 8 \\
\hline Elmadağ & 15 & .77 & 2 \\
\hline Etimesgut & 193 & 9.93 & 38 \\
\hline Evren & 1 & .05 & 0 \\
\hline Gölbaşı & 57 & 2.93 & 10 \\
\hline Güdül & 7 & .36 & 2 \\
\hline Haymana & 10 & .51 & 2 \\
\hline Kalecik & 4 & .21 & 1 \\
\hline Kazan & 28 & 1.44 & 4 \\
\hline Keçiören & 325 & 16.73 & 55 \\
\hline Kızılcahamam & 7 & .36 & 3 \\
\hline Mamak & 223 & 11.48 & 40 \\
\hline Nallıhan & 12 & .62 & 2 \\
\hline Polatlı & 53 & 2.73 & 10 \\
\hline Pursaklar & 55 & 2.83 & 11 \\
\hline Sincan & 231 & 11.89 & 38 \\
\hline Şereflikoçhisar & 13 & .67 & 3 \\
\hline Yenimahalle & 212 & 10.91 & 37 \\
\hline Toplam & 1943 & 100 & 349 \\
\hline
\end{tabular}

Araştırmanın hedef kitlesi Ankara'daki Türk devlet okullarında görev yapan tüm öğretmenlerden oluşurken, araştırmanın örnekleminde Ankara'nın 25 ilçesinden küme örnekleme yöntemi ile seçilen öğretmenler yer almaktadır. Ankara'da 5., 6., 7. ve 8. sınıf seviyelerinde öğretmenlik yapan öğretmenlerin evreni, 12.12.2016 tarihinde www.mebbis.meb.gov.tr adresindeki MEIS modülünden elde edilen verilere göre 1943 öğretmenden oluşmaktadır. Araştırmanın genellenebilirliği için örneklem büyüklüğü önemlidir (Gall, Gall \& Borg (2003). Betimsel çalışmalar için en az 100 katılımcı yeterlidir ve araştırmacılar, sahip oldukları zaman ve enerjiye bağlı olarak mümkün olduğunca büyük 
bir örneğe ulaşabilirler (Fraenkel, Hyun \& Wallen, 2012), araştırmanın güvenilirliği de bu şekilde artabilmektedir (Cohen et al., 2007).

Örneklem büyüklüğü ve diğer tüm bilgiler Tablo 1'de sunulmaktadır. Küme örnekleme yöntemi kullanıldığından, her okulda mevcut olan tüm öğretmenler çalışmaya katılmaya davet edilmiş, bunun sonucu olarak bazı ilçelerde beklenenden daha fazla öğretmen katılmış ve tabloda gösterildiği gibi örnekleme dahil edilmiştir.

\section{Öğretmenlerin Demografik Özellikleri}

Öğretmenlerin demografik özellikleri Tablo 2 sunulmuştur. Tabloda görüldüğü gibi örneklem 280 kadın (\%80.20) ve 69 erkekten (\%19.80) oluşmuştur. Katılımcıların yaş ortalaması 36.50 olarak bulunmuştur. Eğitim düzeyine bakıldığında, 326 öğretmenin (\%93.4) lisans, 22 öğretmenin (\%6.30) yüksek lisans ve 1 öğretmenin (\%.30) doktora derecesine sahip olduğu görülmektedir.

Fakülte türüne göre Eğitim Fakültesinden 207 öğretmen (\%57.30) mezun olurken, 142 öğretmen (\%42.70) diğer bölümlerden mezun olmuştur. Örnek vermek gerekirse, 110 öğretmen (\%31.50) FenEdebiyat Fakültesi'nden, 17 öğretmen (\%6.30) Dil, Tarih ve Coğrafya Fakültesi'nden ve 15 öğretmen (\%4.90) diğer fakültelerden mezun olmuştur. Bölüm tipine göre, Yabancı Dil Eğitimi Bölümü'nden 195 öğretmen (\%55.90), İngiliz Dili ve Edebiyatı Bölümünden 86 öğretmen (\%24.70), Dilbilim Bölümünden 16 öğretmen (\%4.60) mezun olurken, 7 öğretmen (\%2.00) Amerikan Kültürü ve Edebiyatı Bölümü'nden, 1 öğretmen (\%.30) Mütercim Tercümanlık Bölümü'nden, ve 44 öğretmen (\%12.80) diğer bölümlerden mezun oldu. Sınava katılımla ilgili olarak 340 öğretmen $(\% 97,40)$ TOEFL sınavına katılmazken, sadece 9 öğretmen (\%2.60) bu sınava katılmıştır. Aynı şekilde 349 öğretmenden 347 öğretmeni (\%99.40) IELTS sınavına katılmamışken, sadece 2 öğretmenin (\%0.60) katıldığı görülmüştür. Son olarak, 150 öğretmen (\%43.00) YDS sınavına katılmamış, 199 öğretmen (\%57.00) bu sınava katılmış ve YDS sınav sonuçlarının ortalama puanı 84.5 olarak bulunmuştur.

Katılımcıların meslek deneyimleri ile ilgili olarak 76 öğretmenin (\%21.80) 1-5 yıllık, 92 öğretmenin (\%26.40) 6-10 yıl, geri kalan 50 öğretmenin (\%14.30) 20 veya daha fazla deneyime sahipken ve öğretmenlerin en büyük oranının 6-10 yıl (\%26.40) deneyime sahip olduğu görülmektedir. Yurtdışı deneyimleri ve alanlarındaki konferanslara katılıma bakıldığında 142 öğretmenin (\%40.70) yurt dışında bulunmuşken, 207 öğretmen (\%59.30) hiç yurtdışında bulunmamıştır; konferanslara 190 öğretmen (\%54.40) katılırken 159 öğretmen (\%45.60) katılmamıştır.

Katılımcıların ders verdiği sınıflara bakıldığında, tüm öğretmenlerin (\%100) 5., 6., 7. ve 8. sınıf seviyelerine ders verdiği görülmektedir. 2012 yılında geliştirilen öğretim Programı ile ilgili hizmet içi eğitime katılımla ilgili olarak, 143 öğretmen (\%41.00) hizmet içi eğitim alırken, 206 öğretmen (\%59.00) eğitim almamıştır. Hizmet içi eğitim alan 143 öğretmenden (\%41.00), 13 öğretmen (\%9.00) eğitimi yeterince tatmin edici bulurken, 64 öğretmen (\%44.80) eğitimi kısmen tatmin edici bulmuş ve 66 öğretmen (\%46.20) eğitimi yetersiz bulmuştur.

Öğretim Programı hakkında hizmet içi eğitim almayan 206 öğretmen ile hizmet içi eğitim alan 143 öğretmen olduğu ve öğretim programı hakkında daha fazla bilgive farklı şekillerde ulaştıkları görülmektedir. 
Tablo 2

Ankete Kayılan Öğretmenlerin Demografik Özellikleri

\begin{tabular}{|c|c|c|c|c|}
\hline & Kategoriler & $\mathrm{n}$ & $\%$ & $\overline{\mathbf{X}}$ \\
\hline \multirow[t]{2}{*}{ Cinsiyet } & Kadın & 280 & 80.20 & \\
\hline & Erkek & 69 & 19.8. & \\
\hline Yaş & & & & 36.50 \\
\hline \multirow[t]{3}{*}{ Eğitim Seviyesi } & Lisans & 326 & 93.40 & \\
\hline & Yüksek Lisans & 22 & 6.30 & \\
\hline & Doktora & 1 & .30 & \\
\hline \multirow[t]{4}{*}{ Fakülte } & Eğitim & 207 & 57.30 & \\
\hline & Fen-Edebiyat & 110 & 31.50 & \\
\hline & Dil, Tarih ve Coğrafya & 17 & 6.30 & \\
\hline & Diğer & 15 & 4.90 & \\
\hline \multirow[t]{6}{*}{ Bölüm } & İngilizce Öğretmenliği & 195 & 55.90 & \\
\hline & İngiliz Dili ve Edebiyatı & 86 & 24.70 & \\
\hline & İngiliz Dil Bilimi & 16 & 4.60 & \\
\hline & Amerikan Kültürü ve Edebiyatı & 7 & 2.00 & \\
\hline & Mütercim-Tercümanlık & 1 & .30 & \\
\hline & Diğer & 44 & 12.80 & \\
\hline \multirow[t]{2}{*}{ TOEFL Sınavına Katılım } & Evet & 9 & 2.60 & \\
\hline & Hayır & 340 & 97.40 & \\
\hline \multirow[t]{2}{*}{ IELTS Sınavına Katılım } & Evet & 2 & .60 & \\
\hline & Hayır & 347 & 99.40 & \\
\hline \multirow[t]{2}{*}{ YDS Sınavına Katılım } & Evet & 199 & 57.00 & \\
\hline & Hayır & 150 & 43.00 & \\
\hline YDS Sonucu & & & & 84.50 \\
\hline \multirow[t]{5}{*}{ Deneyim } & 1-5 Yıl & 76 & 21.80 & \\
\hline & $6-10$ Y YIl & 92 & 26.40 & \\
\hline & 11-15 Yll & 75 & 21.50 & \\
\hline & $16-20 \mathrm{Yll}$ & 56 & 16.00 & \\
\hline & 20 Yıl üzeri & 50 & 14.30 & \\
\hline \multirow[t]{2}{*}{ Yurtdışı Deneyim } & Evet & 142 & 40.70 & \\
\hline & Hayır & 207 & 59.30 & \\
\hline \multirow[t]{2}{*}{ Kongre Katılımı } & Evet & 190 & 54.40 & \\
\hline & Hayır & 159 & 45.60 & \\
\hline \multirow[t]{4}{*}{ Ders Verilen Sınıflar } & 5. Sinif & 349 & 100.00 & \\
\hline & 6. Sinıf & 349 & 100.00 & \\
\hline & 7. Sinıf & 349 & 100.00 & \\
\hline & 8. Sinif & 349 & 100.00 & \\
\hline Hizmet içi Eğitim & Evet & 143 & 41.00 & \\
\hline Katılım Durumu & Hayır & 206 & 59.00 & \\
\hline Hizmet içi Eğitim Gereksinimleri & Yeterince & 206 & 59.00 & \\
\hline \multirow[t]{2}{*}{ Karşılama Durumu } & Kısmen & 64 & 44.80 & \\
\hline & Karşılamadı & 66 & 46.20 & \\
\hline \multicolumn{5}{|l|}{ Öğretim Programı Hakkındaki } \\
\hline \multirow[t]{5}{*}{ Bilgi Kaynağı } & Kişisel Araştırma & 123 & 35.30 & \\
\hline & Zümre Toplantıları & 107 & 30.70 & \\
\hline & Her İkisi & 12 & 3.40 & \\
\hline & Diğer & 12 & 3.40 & \\
\hline & Toplam & 253 & & \\
\hline
\end{tabular}




\section{Veri Toplama Araçları}

Öğretmenlerin ortaokul İngilizce dersi öğretim programının teorik sağlamlılığına ilişkin algılarını incelemeye çalışan bu araştırmada veri toplamak amacıyla bir anket kullanılmıştır. Başka bir deyişle, öğretim programı tasarımının teorik olarak uygun olup olmadığını bulmak amaçlanmıştır. Geliştirme sürecinde, Mili Eğitim Bakanlığı [MEB] tarafından 2012 yılında geliştirilen en son öğretim programı ve ilgili alanyazın (Çelik, 2009; Er, 2006; Güneş, 2009; Ornstein \& Hunkins, 2004; Mersinligil, 2002; Oliva, 1997; Seçkin, 2010) detaylı bir şekilde incelendi. Illgili literatürden 78 madde bir havuzda toplandı ve daha sonra bu çalışma için uygun olanlar seçildi. Başlangıçta 69 madde seçildi ve anketin içeriği ve geçerliliği ile ilgili algılarını almak üzere uzmanlara gönderildi. Eğitim Programı ve Öğretim Anabilim Dalı'ndan üç Profesör ve İngilizce Öğretmenliği Bölümü'nden bir Profesörden görüşler alındı. Bu uzmanların geri bildirimlerine dayanarak, ankette şekil ve maddeler açısından gerekli değişiklikler yapıldı. Örnek vermek gerekirse, anketin ilk taslağı 69 maddeden oluşmakta iken bazı maddeler silindi, bazı maddeler ise birleştirilerek tek madde halinde yeniden düzenlendi. Ayrıca, anketin formatı da değiştirildi ve bu görüşlere dayanarak bazı yönergeler yeniden düzenlendi. Örneğin, tablolarda görüleceği üzere, programın bileşenleri için farklı cümleler yazmak yerine, bileşenin adı ve ardından maddelerle tamamlanması için üç nokta kullanıldı. Uzman görüşlerinden sonra, anket beş íngilizce öğretmeni tarafından, anketteki maddelerin anlaşııı anlaşılmadığını anlamak amacıyla incelendi ve bu işlem birkaç maddenin ifadelerinde ihmal edilebilir bir revizyonla sonuçlandı. Örnek vermek gerekirse, “öğrenen özerkliği”nin anlamını anlamada zorluk çekiyorlardı, bu yüzden daha kolay anlaşılması için madde yeniden düzenlendi. Son olarak, anket güvenilirliğini kontrol etmek için, anket 65 öğretmene uygulandı ancak 56 öğretmen anketleri doldurdu. Bu bağlamda, geri dönüş oranı \% 86.00 olmuştur. Anketin beş alt bölümü için Cronbach alfa değerleri hedefler, içerik, araç-gereçler, etkinlikler ve değerlendirme yöntem ve teknikleri için sırasıyla $.95, .93, .91, .95$ ve .91 olarak bulundu.

Bütün bu süreçlerden sonra anketin son hali iki bölümden oluştu; ilk bölümde öğretmenlerin demografik özellikleriyle ilgili maddeler bulunurken, ikinci bölümde ise öğretim programı bileşenleri ile ilgili maddeler yer aldı. Anketin bu ikinci bölümünde beş alt bölüm ve 56 madde yer almaktadır. Birinci alt bölüm hedeflerle ilgili 17 madde, ikinci alt bölüm içerikle ilgili 12 madde, üçüncü alt bölüm ise araçgereçlerle ilgili altı madde, dördüncü alt bölüm etkinliklerle ilgili 14 madde ve son bölümde ise değerlendirme yöntem ve teknikleri ile ilgili yedi madde yer aldı. Anket, beş maddelik Likert tipi ölçeğinde modellenmiştir; burada öğretmenlerden, her bir maddeyi "1 - kesinlikle katılmıyorum, 2 katılmıyorum, 3 ne katılıyorum ne katılmıyorum, 4- katılıyorum, 5- katılıyorum" gibi beş puanlık bir ölçekte derecelendirerek o maddelere katılma veya katılmama düzeylerini derecelendirmeleri istenmiştir.

\section{Veri Toplama Süreci}

Veri toplanmadan önce gerekli izinler alınmıştır. İlk olarak, veri toplama araçları incelenmek üzere Orta Doğu Teknik Üniversitesi İnsan Kaynakları Etik Komitesi'ne (IAEK) gönderilmiştir. 02.01.2017 tarihinde İAEK'den izin alındıktan sonra Ankara II Milli Eğitim Müdürlüğü'ne resmi izin için başvuru yapılmıştır. 18.04.2017 tarihinde Ankara İ Milli Eğitim Müdürlüğü’nün onayı alındıktan sonra, ana çalışma için veri toplanmaya başlandı.

Veriler araştırmacılardan biri tarafından seçilen okullar ziyaret edilerek toplandı. Ziyaret sırasında, araştırmacı kendini tüm okul yöneticilerine tanıtarak araştırmanın amacı hakkında onları bilgilendirdi. Ardından Ankara İl Milli Eğitim Müdürlüğü'nün onayı ya onlara gösterildi ya da bir nüshası kendilerine bırakıldı. Öğretmenler ya araştırmacı oradayken anketi doldurmuş ya da araştırmacının başka bir gün geri gelmesini istediler. Bu bağlamda, araştırmacı bazı okulları iki hatta üç kez ziyaret etmek zorunda kaldı. Öğretmenlerin çoğunluğu anketi 10 dakika süren teneffüslerde tamamlayabilirken bazıları bir teneffüste bitiremedi ve başka bir teneffüste bitirebildi. 


\section{Verilerin Analizi}

Veriler ortalamalar, frekanslar ve yüzdeler gibi betimleyici istatistik prosedürleri ile analiz edilmiştir. Verilere bağlı olarak, bulguları rapor ederken ya ortalama ya da sıklık ve yüzdeler kullanılmıştır.

\section{Bulgular}

İngilizce öğretmenlerinin 5., 6., 7. ve 8. sınıf düzeyleri için hazırlanan ortaokul İngilizce dersi öğretim programının bileşenlerine ilişkin algılarına yönelik bulgular alt başılılarla sunulmuştur.

\section{Öğretmenlerin Ortaokul Ingilizce Dersi Öğretim Programının Kazanımlarına ilişkin Algıları}

\section{Tablo 3}

Öğretmenlerin Ortaokul Ingilizce Dersi Öğretim Programının Hedeflerine ilişkin Algıları

\begin{tabular}{|c|c|c|c|c|c|c|c|c|c|c|}
\hline \multirow{2}{*}{ Kazanımlar } & \multicolumn{2}{|c|}{ 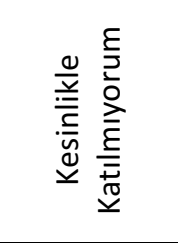 } & \multicolumn{2}{|c|}{ 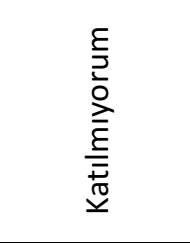 } & \multicolumn{2}{|c|}{ 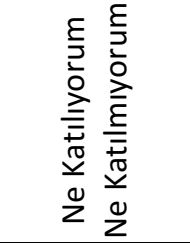 } & \multicolumn{2}{|c|}{ 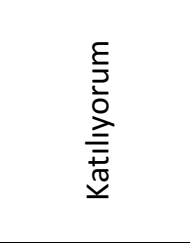 } & \multicolumn{2}{|c|}{ 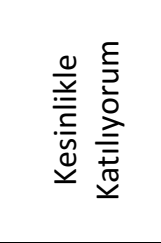 } \\
\hline & $f$ & $\%$ & $f$ & $\%$ & $f$ & $\%$ & $f$ & $\%$ & $f$ & $\%$ \\
\hline $\begin{array}{l}\text {...Ingilizce programının genel } \\
\text { amaçları ile tutarlıdır. }\end{array}$ & 14 & 4.00 & 58 & 16.60 & 88 & 25.20 & 163 & 46.70 & 26 & 7.40 \\
\hline ...gerçekleştirilebilir niteliktedir. & 10 & 2.90 & 56 & 16.00 & 95 & 27.20 & 164 & 47.00 & 24 & 6.90 \\
\hline $\begin{array}{l}\text {...gözlenebilir ve ölçülebilir } \\
\text { niteliktedir. }\end{array}$ & 9 & 2.60 & 38 & 10.90 & 115 & 33.00 & 162 & 46.40 & 25 & 7.20 \\
\hline $\begin{array}{l}\text {...öğrencilerin günlük yaşamında } \\
\text { kullanabileceği niteliktedir. }\end{array}$ & 23 & 6.60 & 86 & 24.60 & 92 & 26.40 & 108 & 30.90 & 40 & 11.50 \\
\hline $\begin{array}{l}\text {...kendi içerisinde tutarlı bir sıra } \\
\text { izlemektedir. }\end{array}$ & 21 & 6.00 & 70 & 20.10 & 113 & 32.40 & 114 & 32.70 & 31 & 8.90 \\
\hline ...ünite sürelerinde & 24 & 6.90 & 72 & 20.60 & 64 & 18.30 & 144 & 41.30 & 45 & 12.90 \\
\hline gerçekleştirilebilir niteliktedir. & & & & & & & & & & \\
\hline $\begin{array}{l}\text {....iletişimsel yeterliği geliştirebilir } \\
\text { niteliktedir. }\end{array}$ & 29 & 8.30 & 107 & 30.70 & 123 & 35.20 & 77 & 22.10 & 12 & 3.40 \\
\hline ...öğrencinin kendi kendine & 67 & 19.20 & 143 & 41.00 & 85 & 24.40 & 37 & 10.60 & 17 & 4.90 \\
\hline öğrenmesini sağlayıcı niteliktedir. & & & & & & & & & & \\
\hline $\begin{array}{l}\text {...dinleme becerisini geliştirebilecek } \\
\text { niteliktedir. }\end{array}$ & 39 & 11.20 & 99 & 28.40 & 98 & 28.10 & 99 & 28.40 & 14 & 4.00 \\
\hline $\begin{array}{l}\text {...dinleme becerisini geliştirmek için } \\
\text { yeterli sayıdadır. }\end{array}$ & 45 & 12.90 & 128 & 36.70 & 89 & 25.50 & 70 & 20.10 & 17 & 4.90 \\
\hline $\begin{array}{l}\text {...konuşma becerisini geliştirebilecek } \\
\text { niteliktedir. }\end{array}$ & 42 & 12.00 & 138 & 39.50 & 88 & 25.20 & 71 & 20.30 & 10 & 2.90 \\
\hline $\begin{array}{l}\text {...konuşma becerisini geliştirmek için } \\
\text { yeterli sayıdadır. }\end{array}$ & 54 & 15.50 & 134 & 38.40 & 105 & 30.10 & 41 & 11.70 & 15 & 4.30 \\
\hline $\begin{array}{l}\text {...yazma becerisini geliştirebilecek } \\
\text { niteliktedir. }\end{array}$ & 28 & 8.00 & 103 & 29.50 & 94 & 26.90 & 106 & 30.40 & 18 & 5.20 \\
\hline $\begin{array}{l}\text {...yazma becerisini geliştirmek için } \\
\text { yeterli sayıdadır. }\end{array}$ & 39 & 11.20 & 109 & 31.20 & 101 & 28.90 & 83 & 23.80 & 17 & 4.90 \\
\hline $\begin{array}{l}\text {...okuma becerisini geliştirebilecek } \\
\text { niteliktedir. }\end{array}$ & 17 & 4.90 & 55 & 15.80 & 83 & 23.80 & 151 & 43.30 & 43 & 12.30 \\
\hline $\begin{array}{l}\text {...okuma becerisini geliştirmek için } \\
\text { yeterli sayıdadır. }\end{array}$ & 18 & 5.20 & 66 & 18.90 & 87 & 24.90 & 130 & 37.20 & 48 & 13.80 \\
\hline $\begin{array}{l}\text {...öğrencilerin gelişim düzeylerine } \\
\text { uygundur. }\end{array}$ & 20 & 5.70 & 65 & 18.60 & 104 & 29.80 & 111 & 31.80 & 49 & 14.00 \\
\hline
\end{tabular}

Öğretmenlerin İngilizce dersi öğretim programının amaçları hakkındaki algılarına ilişkin bulgular Tablo 3'te özetlenmiştir. Bulgular rapor edilirken, maddelere katılan veya kesinlikle katılan katılımcıların sayısı ve yüzdeleri ile katılmayan veya kesinlikle katılmayan katılımcıların sayısı ve yüzdeleri kendi aralarında toplandı. Tablo 3'te görüldüğü üzere, öğretmenlerin yaklaşık \%42.00'si 
( $n=147)$ ile \%56.00'sı ( $n=195)$ hedeflerin İngilizce dersi öğretim programının genel amaçları ile uyumlu olduğunu (\%54.10), ulaşılabilir nitelikte olduğunu (\%53.90), gözlenebilir ve ölçülebilir nitelikte (\%53.60), öğrencilerin günlük yaşamında kullanabileceği nitelikte olduğunu (\%42.40), kendi içerisinde tutarlı bir sıra izlediğini (\%41.60), ünite sürelerinde gerçekleştirilebilir nitelikte olduğunu (\%54.20), okuma becerisini geliştirebilecek nitelikte olduğunu (\%55.60), okuma becerisini geliştirmek için yeterli sayıda olduğunu (\%51.00), ve öğrencilerin gelişim düzeylerine uygun olduğunu (\%45.80) belirttiler. Diğer yandan, öğretmenlerin yaklaşık \%13.00 $(n=45)$ ile \%31.00'i $(n=108)$ yukarıda belirtilen özelliklere ya katılmadığını ya da kesinlikle katılmadığını belirtirken \%18.00 ( $n=62)$ ile \%33.00'ü $(n=115)$ bu özelliklere ne katıldıklarını ne de katılmadıklarını belirttiler.

Ayrıca, öğretmenlerin yaklaşık \%38.00 (n=133) ile \%60.00’ $(n=209)$ kazanımların, iletişimsel yeterliği geliştiremeyeceğini (\%39.00), öğrencinin kendi kendine öğrenmesini sağlayıcı nitelikte olmadığını (\%60.20), dinleme becerisini geliştirebilecek nitelikte olmadığını (\%39.60), dinleme becerisini geliştirmek için yeterli sayıda olmadığını (\%49.60), konuşma becerisini geliştirebilecek nitelikte olmadığını (\%51.50), konuşma becerisini geliştirmek için yeterli sayıda olmadığını (\%53.90), yazma becerisini geliştirebilecek nitelikte olmadığını (\%37.50), ve yazma becerisini geliştirmek için yeterli sayıda olmadığını (\%42.40) belirttiler. Diğer yandan, öğretmenlerin yaklaşık \% $15.00(n=52)$ ile \% 35.00'i ( $n=122$ ) yukarıda belirtilen özelliklere ya katıldığını ya da kesinlikle katıldığını belirtirken, \%24.00 ( $n=84$ ) ile \%35.00'ü ( $n=122$ ) ise bu özelliklere ne katıldıklarını ne de katılmadıklarını belirttiler.

\section{Öğretmenlerin Ortaokul Ingilizce Dersi öğretim Programının Içeriğine ilişkin Algıları}

Tablo 4

Öğretmenlerin Ortaokul Ingilizce Dersi Öğretim Programının Içceriğine ilişkin Algıları

\begin{tabular}{|c|c|c|c|c|c|c|c|c|c|c|}
\hline \multirow{2}{*}{ İçerik } & \multicolumn{2}{|c|}{ 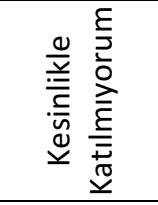 } & \multicolumn{2}{|c|}{ 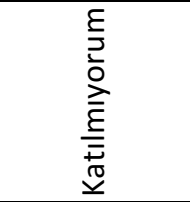 } & \multicolumn{2}{|c|}{ 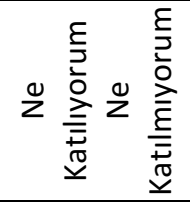 } & \multicolumn{2}{|r|}{ 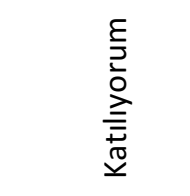 } & \multicolumn{2}{|c|}{ 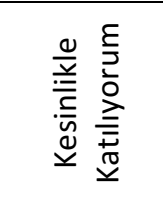 } \\
\hline & $f$ & $\%$ & $f$ & $\%$ & $f$ & $\%$ & $f$ & $\%$ & $f$ & $\%$ \\
\hline ...kazanımlarla tutarlıdır. & 9 & 2.60 & 36 & 10.30 & 97 & 27.80 & 168 & 48.10 & 39 & 11.20 \\
\hline $\begin{array}{l}\text {...öğrencinin ilgi ve ihtiyaçlarına } \\
\text { uygundur. }\end{array}$ & 19 & 5.40 & 82 & 23.50 & 110 & 31.50 & 98 & 28.10 & 40 & 11.50 \\
\hline $\begin{array}{l}\text {...öğrencinin gelişim özelliklerine } \\
\text { uygundur. }\end{array}$ & 14 & 4.00 & 59 & 16.90 & 112 & 32.10 & 123 & 35.20 & 41 & 11.70 \\
\hline $\begin{array}{l}\text {...öğrencinin derse aktif katılımını } \\
\text { sağlayabilecek niteliktedir. }\end{array}$ & 21 & 6.00 & 69 & 19.80 & 124 & 35.50 & 107 & 30.70 & 27 & 7.70 \\
\hline $\begin{array}{l}\text {...kazanımlara ulaşılmasıını } \\
\text { sağlayabilecek niteliktedir. }\end{array}$ & 14 & 4.00 & 48 & 13.80 & 130 & 37.20 & 128 & 36.70 & 29 & 8.30 \\
\hline $\begin{array}{l}\text {...öğrencilerin günlük hayatta } \\
\text { kullanabileceği bilgiler içermektedir. }\end{array}$ & 14 & 4.00 & 66 & 18.90 & 107 & 30.70 & 134 & 38.40 & 28 & 8.00 \\
\hline ...kendi içinde tutarlıdır. & 14 & 4.00 & 44 & 12.60 & 115 & 33.00 & 151 & 43.30 & 25 & 7.20 \\
\hline $\begin{array}{l}\text {...yazma becerisini geliştirebilecek } \\
\text { niteliktedir. }\end{array}$ & 21 & 6.00 & 93 & 26.60 & 108 & 30.90 & 114 & 32.70 & 13 & 3.70 \\
\hline $\begin{array}{l}\text {...okuma becerisini geliştirebilecek } \\
\text { niteliktedir. }\end{array}$ & 8 & 2.30 & 68 & 19.50 & 91 & 26.10 & 154 & 44.10 & 28 & 8.00 \\
\hline $\begin{array}{l}\text {...dinleme becerisini geliştirebilecek } \\
\text { niteliktedir. }\end{array}$ & 19 & 5.40 & 112 & 32.10 & 103 & 29.50 & 98 & 28.10 & 17 & 4.90 \\
\hline $\begin{array}{l}\text {...konuşma becerisini geliştirebilecek } \\
\text { niteliktedir. }\end{array}$ & 26 & 7.40 & 134 & 38.40 & 97 & 27.80 & 78 & 22.30 & 14 & 4.00 \\
\hline $\begin{array}{l}\text {...belirlenen zaman süresi içinde } \\
\text { tamamlanabilecek niteliktedir. }\end{array}$ & 31 & 8.90 & 69 & 19.80 & 80 & 22.90 & 136 & 39.00 & 33 & 9.50 \\
\hline
\end{tabular}

Öğretmenlerin İngilizce dersi öğretim programının amaçları hakkındaki algılarına ilişkin bulgular Tablo 4'te özetlenmiştir. Tabloda görüldüğü üzere, öğretmenlerin yaklaşık \%37.00'si ( $n=147)$ ile \% 59.00 'u ( $n=195$ ) içeriğin kazanımlar ile tutarlı olduğunu (\%59.30), öğrencilerin ihtiyaçları ve ilgi alanları 
için uygun olduğunu (\%39.60), öğrencilerin gelişim düzeyleri için uygun olduğunu (\%46.90), öğrencilerin aktif katılımını sağlayabilecek nitelikte olduğunu (\%38.40), hedeflerin gerçekleştirilmesini sağlayabilecek nitelikte olduğunu (\%45.00), öğrencilerin hayatlarında kullanabilecekleri bilgiler içerdiğini (\%46.40), kendi içinde tutarlı olduğunu (\%50.50), okuma becerilerini geliştirebilecek nitelikte olduğunu (\%52.10) ve belirlenen zaman süresi içinde tamamlanabilecek nitelikte olduğunu (\%48.50) belirttiler. Diğer yandan, öğretmenlerin yaklaşık \%16.00 ( $n=56)$ ile \%29.00'u $(n=101)$ yukarıda belirtilen özelliklere ya katılmadığını ya da kesinlikle katılmadığını belirtirken, \%23.00 ( $n=80)$ ile \%37.00'si ( $n=129$ ) bu özelliklere ne katıldıklarını ne de katılmadıklarını belirttiler.

Ayrıca, öğretmenlerin yaklaşık \%33.00 ( $n=115)$ ile \%38.00'inin ( $n=133)$ öğretim programının içeriği ile ilgili bazı özelliklere katılmadığını veya kesinlikle katılmadığını göstermiştir. Örnek vermek gerekirse, katıımcılar içeriğin yazma becerilerini (\%32.60), dinleme becerilerini (\%37.50) ve konuşma becerilerini (\%35.80) geliştirebilecek nitelikte olmadığını belirttiler. Öte yandan, öğretmenlerin yaklaşık \%26.00 ( $\mathrm{n}=91$ ) ile \%36.00'sı ( $\mathrm{n=126)}$, içeriğin yukarıda belirtilen yönlerine ya katıldığını ya da kesinlikle katıldığını belirtirken, yaklaşık \%26.00 ( $n=91)$ ile \%30.00'u ( $n=105)$ bu özelliklere ne katıldıklarını, ne de katılmadıklarını belirttiler.

\section{Öğretmenlerin Ortaokul Ingilizce Dersi Öğretim Programının Araç-Gereçlerine ilişskin Algıları}

Öğretmenlerin İngilizce dersi öğretim programının araç-gereçleri hakkındaki algılarına ilişkin bulgular Tablo 5 'te özetlenmiştir.

Tablo 5

Öğretmenlerin Ortaokul Ingilizce Dersi Öğretim Programının Araç-Gereçlerine iliş̧kin Algıları

\begin{tabular}{|c|c|c|c|c|c|c|c|c|c|c|}
\hline \multirow[t]{2}{*}{ Araç-gereçler } & \multicolumn{2}{|c|}{ 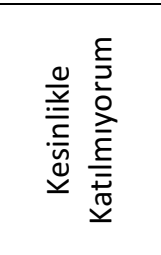 } & \multicolumn{2}{|c|}{ 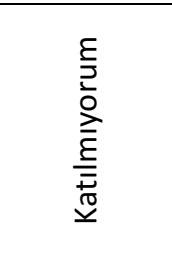 } & \multicolumn{2}{|c|}{ 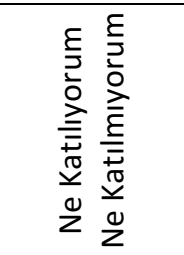 } & \multicolumn{2}{|c|}{ 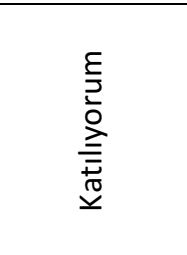 } & \multicolumn{2}{|c|}{ 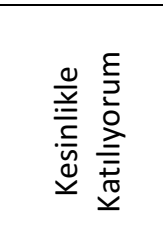 } \\
\hline & $f$ & $\%$ & $f$ & $\%$ & $f$ & $\%$ & $f$ & $\%$ & $f$ & $\%$ \\
\hline $\begin{array}{l}\text {...kazanımlara ulaşılmasını destekleyici } \\
\text { niteliktedir. }\end{array}$ & 20 & 5.70 & 85 & 24.40 & 96 & 27.50 & 113 & 32.40 & 35 & 10.00 \\
\hline $\begin{array}{l}\text {...öğrencinin derse aktif katılımını } \\
\text { destekleyici niteliktedir. }\end{array}$ & 20 & 5.70 & 83 & 23.80 & 110 & 31.50 & 108 & 30.90 & 28 & 8.00 \\
\hline $\begin{array}{l}\text {...öğrencinin derse ilgisini arttırabilecek } \\
\text { niteliktedir. }\end{array}$ & 22 & 6.30 & 88 & 25.20 & 118 & 33.80 & 94 & 26.90 & 27 & 7.70 \\
\hline ...kolayca ulaşılabilecek niteliktedir. & 17 & 4.90 & 62 & 17.80 & 89 & 25.50 & 146 & 41.80 & 35 & 10.00 \\
\hline $\begin{array}{l}\text {...öğrencinin öğrendikleri bilgileri } \\
\text { pekiştirebilir niteliktedir. }\end{array}$ & 19 & 5.40 & 67 & 19.20 & 111 & 31.80 & 123 & 35.20 & 29 & 8.30 \\
\hline ...öğrencilerin yaş grubuna uygundur. & 15 & 4.30 & 52 & 14.90 & 93 & 26.60 & 139 & 39.80 & 50 & 14.30 \\
\hline
\end{tabular}

Tabloda görüldüğü gibi, öğretmenlerin yaklaşık \%35.00 ( $n=122)$ ile \%54.00'ü $(n=189)$, araçgereçlerin kazanımlara ulaşımasını destekleyici nitelikte olduğunu (\%42.40), öğrencinin derse aktif katılımını destekleyici nitelikte olduğunu (\%38.90), öğrencinin derse ilgisini arttırabilecek nitelikte olduğunu (\%34.60), kolayca ulaşılabilecek nitelikte olduğunu (\%51.80), öğrencilerin öğrendikleri bilgileri pekiştirebilir nitelikte olduğunu (\%43.50) ve öğrencilerin yaş grubuna uygun olduğunu (\% 54.10) belirttiler. Öte yandan, öğretmenlerin yaklaşık \%19.00 ( $n=66)$ ile \%31.00'i $(n=108)$, araçgereçlerin belirtilen yönlerine ya katılmadığını ya da kesinlikle katılmadığını belirtirken ve yaklaşık \%25.00 ( $n=87$ ) ile \%34.00'ü ( $n=118$ ) bu özelliklere ne katıldıklarını ne de katılmadıklarını belirttiler.

\section{Öğretmenlerin Ortaokul Ingilizce Dersi Öğretim Programının Etkinliklerine ilişkin Algıları}

Öğretmenlerin İngilizce dersi öğretim programının etkinlikleri hakkındaki algılarına ilişkin bulgular Tablo 6'da sunulmuştur. Tabloda görüldüğü gibi, öğretmenlerin yaklaşık \%36.00 ( $n=126)$ ile \%51.00'i ( $n=178$ ), etkinliklerin öğrencinin İngilizceye ilişkin olumlu tutum geliştirmesini destekleyici nitelikte olduğunu (\% 36.10), öğrencinin derse aktif olarak katılımını destekleyici nitelikte olduğunu (\%37.60), 
kazanımlara ulaşılmasını destekleyici nitelikte olduğunu (\%45.20), öğrencilerin gelişim düzeyine uygun nitelikte olduğunu (\%48.90), öğrencilerin günlük yaşamı ile ilişkili olduğunu (\%46.40), öğrencinin okuma becerisini geliştirebilecek nitelikte olduğunu (\%50.70), sınıfta uygulanabilecek nitelikte olduğunu (\%49.90) ve öğrenci merkezli olduğunu (\%49.30) belirttiler. Öte yandan, öğretmenlerin yaklaşık \%20.00 ( $n=69)$ ile \%29.00'u ( $n=101)$, etkinliklerin belirtilen yönlerine ya katılmadığını ya da kesinlikle katılmadığını belirtirken, yaklaşık \%27.00 ( $n=94)$ ile \%36.00'sı ( $n=118)$ bu özelliklere ne katıldıklarını ne de katılmadıklarını belirttiler.

\section{Tablo 6}

Öğretmenlerin Ortaokul Ingilizce Dersi Öğretim Programının Etkinliklerine iliş̧kin Algıları

\begin{tabular}{|c|c|c|c|c|c|c|c|c|c|c|}
\hline \multirow[t]{2}{*}{ Etkinlikler } & \multicolumn{2}{|c|}{ 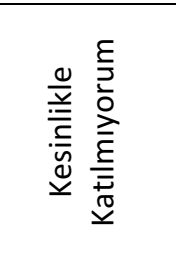 } & \multicolumn{2}{|c|}{ 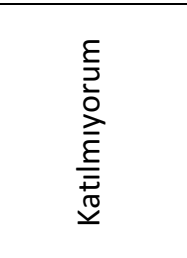 } & \multicolumn{2}{|c|}{ 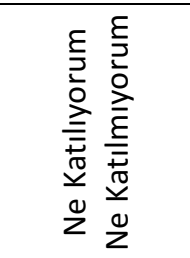 } & \multicolumn{2}{|c|}{ 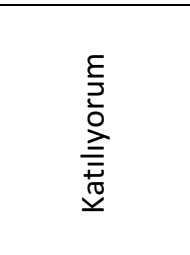 } & \multicolumn{2}{|c|}{ 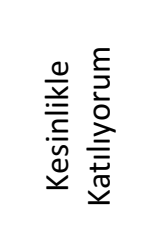 } \\
\hline & $f$ & $\%$ & $f$ & $\%$ & $f$ & $\%$ & $f$ & $\%$ & $f$ & $\%$ \\
\hline $\begin{array}{l}\text {...öğrencinin İngilizce'ye karşı olumlu } \\
\text { tutum geliştirmesini destekleyici } \\
\text { niteliktedir. }\end{array}$ & 17 & 4.90 & 84 & 24.10 & 122 & 35.00 & 107 & 30.70 & 19 & 5.40 \\
\hline $\begin{array}{l}\text {...öğrencinin derse aktif olarak katılımını } \\
\text { destekleyici niteliktedir. }\end{array}$ & 18 & 5.20 & 73 & 20.90 & 127 & 36.40 & 107 & 30.70 & 24 & 6.90 \\
\hline $\begin{array}{l}\text {...kazanımlara ulaşılmasını destekleyici } \\
\text { niteliktedir. }\end{array}$ & 14 & 4.00 & 60 & 17.20 & 117 & 33.50 & 131 & 37.50 & 27 & 7.70 \\
\hline $\begin{array}{l}\text {...öğrencilerin gelişim düzeyine uygun } \\
\text { niteliktedir. }\end{array}$ & 9 & 2.60 & 67 & 19.20 & 102 & 29.20 & 128 & 36.70 & 43 & 12.20 \\
\hline ...öğrencilerin günlük yaşamı ile ilişkilidir. & 13 & 3.70 & 72 & 20.60 & 102 & 29.20 & 125 & 35.80 & 37 & 10.60 \\
\hline $\begin{array}{l}\text {...'iletişimsel yeterliği' geliştirebilecek } \\
\text { niteliktedir. }\end{array}$ & 22 & 6.30 & 112 & 32.10 & 112 & 32.10 & 88 & 25.20 & 15 & 4.30 \\
\hline $\begin{array}{l}\text {...öğrencinin dinleme becerisini } \\
\text { geliştirebilecek niteliktedir. }\end{array}$ & 26 & 7.40 & 104 & 29.80 & 103 & 29.50 & 99 & 28.40 & 17 & 4.90 \\
\hline $\begin{array}{l}\text {...öğrencinin okuma becerisini } \\
\text { geliştirebilecek niteliktedir. }\end{array}$ & 13 & 3.70 & 67 & 19.20 & 92 & 26.40 & 148 & 42.40 & 29 & 8.30 \\
\hline $\begin{array}{l}\text {...öğrencinin yazma becerisini } \\
\text { geliştirebilecek niteliktedir. }\end{array}$ & 25 & 7.20 & 101 & 28.90 & 99 & 28.40 & 107 & 30.70 & 17 & 4.90 \\
\hline $\begin{array}{l}\text {...öğrencinin konuşma becerisini } \\
\text { geliştirebilecek niteliktedir. }\end{array}$ & 34 & 9.70 & 116 & 33.20 & 97 & 27.80 & 85 & 24.40 & 17 & 4.90 \\
\hline ...sınıfta uygulanabilecek niteliktedir. & 13 & 3.70 & 58 & 16.60 & 104 & 29.80 & 149 & 42.70 & 25 & 7.20 \\
\hline ...öğrenci merkezlidir. & 14 & 4.00 & 68 & 19.50 & 95 & 27.20 & 133 & 38.10 & 39 & 11.20 \\
\hline $\begin{array}{l}\text {...öğrencinin bağımsız çalışma becerisini } \\
\text { destekleyici niteliktedir. }\end{array}$ & 27 & 7.70 & 113 & 32.40 & 126 & 36.10 & 69 & 19.80 & 14 & 4.00 \\
\hline $\begin{array}{l}\text {...öğrencilerin bireysel farklılıklarına } \\
\text { uygundur. }\end{array}$ & 60 & 17.00 & 126 & 36.30 & 107 & 30.70 & 51 & 14.60 & 5 & 1.40 \\
\hline
\end{tabular}

Ayrıca, öğretmenlerin yaklaşık \%36.00 ( $n=126)$ ile \%53.00'ünün $(n=185)$ önerilen faaliyetlerin altı özelliğine katılmadıklarını veya kesinlikle katılmadıklarını göstermiştir. Bu bulgular, etkinliklerin öğrencilerin iletişimsel yeterliliğini (\%38.4), bağımsız çalışma becerisini (\%40.10), dinleme becerilerini (\%37.20), yazma becerilerini (\%36.10), ve konuşma becerilerini (\%42.90) geliştirebilecek nitelikte olmadığını ve öğrencilerin bireysel farklılıklarına uygun olmadığını (\%53.30) belirttiler. Öte yandan, öğretmenlerin yaklaşık \%16 $(n=55)$ ile $\% 35^{\prime} i(n=122)$, etkinliklerin yukarıda belirtilen yönlerine ya katıldığını ya da kesinlikle katıldığını belirtirken ve yaklaşık \%26.00 ( $n=91)$ ile \%36.00'sı $(n=125)$ bu özelliklere ne katılıklarını ne de katılmadıklarını belirttiler. 


\section{Öğretmenlerin Ortaokul Ingilizce Dersi Öğretim Programının Değerlendirme Yöntem ve Tekniklerine ilişkin Algıları}

Öğretmenlerin İngilizce dersi öğretim programının değerlendirme yöntem ve teknikleri hakkındaki algılarına ilişkin bulgular Tablo 7'de sunulmuştur.

\section{Tablo 7}

Öğretmenlerin Ortaokul Ingilizce Dersi Öğretim Programının Değerlendirme Yöntem ve Tekniklerine iliş̧kin Algıları

\begin{tabular}{|c|c|c|c|c|c|c|c|c|c|c|}
\hline \multirow{2}{*}{$\begin{array}{l}\text { Değerlendirme Yöntem ve } \\
\text { Teknikleri }\end{array}$} & \multicolumn{2}{|c|}{ 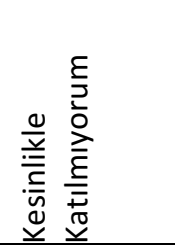 } & \multirow[t]{2}{*}{ 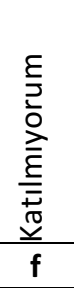 } & \multicolumn{3}{|c|}{ 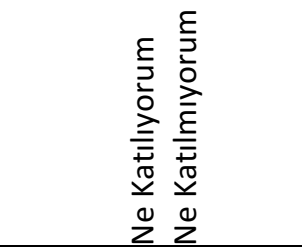 } & \multicolumn{2}{|c|}{ 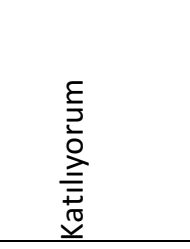 } & \multicolumn{2}{|c|}{ 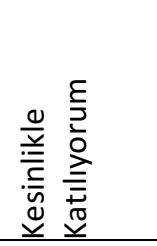 } \\
\hline & $f$ & $\%$ & & $\%$ & $f$ & $\%$ & $f$ & $\%$ & $f$ & $\%$ \\
\hline ...uygulanabilecek niteliktedir. & 13 & 3.70 & 52 & 14.90 & 98 & 28.10 & 163 & 46.70 & 23 & 6.60 \\
\hline ...kazanımlarla tutarlıdır. & 7 & 2.00 & 48 & 13.80 & 84 & 24.10 & 177 & 50.70 & 33 & 9.50 \\
\hline $\begin{array}{l}\text {...öğrencilerin gelişim düzeylerini } \\
\text { dikkate almaktadır. }\end{array}$ & 9 & 2.60 & 71 & 20.30 & 110 & 31.50 & 134 & 38.40 & 25 & 7.20 \\
\hline $\begin{array}{l}\text {...öğrencilerin dinleme becerilerini } \\
\text { değerlendirebilecek niteliktedir. }\end{array}$ & 26 & 7.40 & 111 & 31.80 & 108 & 30.90 & 87 & 24.90 & 17 & 4.90 \\
\hline $\begin{array}{l}\text {...öğrencilerin okuma becerilerini } \\
\text { değerlendirebilecek niteliktedir. }\end{array}$ & 12 & 3.40 & 59 & 16.90 & 97 & 27.80 & 141 & 40.50 & 40 & 11.50 \\
\hline $\begin{array}{l}\text {...öğrencilerin konuşma becerilerini } \\
\text { değerlendirebilecek niteliktedir. }\end{array}$ & 37 & 10.60 & 107 & 30.70 & 115 & 33.00 & 72 & 20.60 & 18 & 5.20 \\
\hline $\begin{array}{l}\text {...öğrencilerin yazma becerilerini } \\
\text { değerlendirebilecek niteliktedir. }\end{array}$ & 28 & 8.00 & 83 & 23.80 & 100 & 28.70 & 121 & 34.70 & 17 & 4.90 \\
\hline
\end{tabular}

Tabloda görüldüğü gibi, öğretmenlerin yaklaşık \%40.00 ( $n=140)$ ile \%60.00'ı ( $n=209)$, önerilen değerlendirme yöntem ve tekniklerinin uygulanabilecek nitelikte (\%53.30), kazanımlarla tutarlı (\%60.20), öğrencilerin gelişim seviyelerini dikkate aldığını (\%45.60), öğrencilerin okuma becerilerini (\%52.00) ve yazma becerilerini değerlendirebilecek nitelikte olduğunu (\%39.60) belirttiler. Diğer yandan, öğretmenlerin yaklaşık \%15.00 ( $n=52)$ ile \%31.00'i $(n=108)$, değerlendirme yöntem ve tekniklerinin belirtilen yönlerine ya katılmadığını ya da kesinlikle katılmadığını belirtirken, yaklaşık \%24.00 ( $n=44)$ ile \%31.00'i ( $n=108)$ bu özelliklere ne katılılarını ne de katılmadıklarını belirttiler.

Ayrıca, öğretmenlerin yaklaşık \%36.00 ( $n=126)$ ile \%53.00'ünün $(n=185)$ ise önerilen değerlendirme yöntem ve tekniklerinin öğrencilerin dinleme becerilerini (\%39.20) ve konuşma becerilerini ölçemeyeceğini (\%41.30) belirttiler. Diğer yandan, öğretmenlerin yaklaşık \%25.00 ( $n=87)$ ile \%29.00'u $(n=101)$, değerlendirme yöntem ve tekniklerinin belirtilen becerilerin ölçülebileceği yönünde fikir belirtirken ve yaklaşık \%30.00 $(n=104)$ ile \% 33.00'ü $(n=115)$ ise bu konuda kararsız olduklarını belirttiler.

\section{Tartışma, Sonuç ve Öneriler}

Araştırmada İngilizce öğretmenlerinin ortaokul İngilizce dersi öğretim programı hakkındaki algılarını incelemek amaçlanmıştır. Araştırma sorusunu cevaplamak için iki bölümden oluşan bir anket kullanılmıştır. Illk bölümde öğretmenlerin demografik özellikleri ile ilgili maddeler, ikinci bölümde ise öğretim programının bileşenleri ile ilgili maddeler yer almıştır.

Katılımcıların demografik özelliklerine ilişkin sonuçlarla başlamak gerekirse, erkeklerden daha fazla kadın olduğu, hemen hemen tüm öğretmenlerin lisans derecesine sahip olduğu, yaklaşık beşte üçünün yabancı dil eğitimi bölümünden mezun olduğu, yaklaşık beşte üçünün YDS'ye katıldığı, ancak TOEFL ve IELTS'e neredeyse hiç katılım olmadığı, sadece beşte ikisinin daha önce yurt dışında bulunduğu, beşte üçünden fazlasının mesleği hakkında herhangi bir yayını takip etmediği, beşte ikisi de mesleği hakkında 
herhangi bir yayını takip etmedi, meslekleriyle ilgili konferansa katılanlarla katılmayanların sayısının neredeyse eşit olduğu ve hepsinin 4 sınıf düzeyinde ders verdiği sonuçlarına varılmıştır. Ortaokul İngilizce öğretim programı hakkındaki bilgi kaynakları ile ilgili olarak, katılımcıların yalnızca beşte ikisinin hizmet içi eğitime katıldığı, katılanlar arasında sadece onda birinin hizmet içi eğitimi yeterince tatmin edici bulduğu, bu yüzden esas olarak zümre toplantılarında veya kişisel araştırmaları ile program hakkında bilgi edindikleri sonucuna varılmıştır.

Demografik özelliklerin gösterdiği gibi, öğretmenlerin çoğu beklendiği gibi yabancı dil bölümü mezunudur. Sadece okuduğunu anlama becerilerini ölçen YDS sınavı sonuçlarına bakııdığında bu alanda başarılı oldukları söylenebilir, fakat dinleme, konuşma ve yazma becerilerindeki yeterliliklerini ölçebilecek TOEFL ve IELTS sınavlarına neredeyse hiç katılmadıkları için bu becerilerdeki yeterlikleri hakkında bir bulguya ulaşılamamıştır. Ayrıca, öğretmenlerin alanlarındaki son gelişmelere paralel olarak kendilerini geliştirmedikleri sonucuna varılmıştır. Yaman (2010) ve Tekin-Özel (2011) tarafından elde edilen sonuçlara benzer şekilde, bu sonuç öğretmenlerin çoğunun ortaokul ingilizce öğretim programı hakkında herhangi bir hizmet içi eğitime katılmadığını, program hakkındaki bilgilerinin zümre toplantıları veya kişisel araştırmaları ile sınırlı olduğu sonucuna varılmıştır. Bu nedenle, yeni programın öğretmenlerin programı uygulama biçiminde herhangi bir değişikliğe neden olması beklenemez.

Öğretmenlerin programın bileşenleri hakkındaki algılarına ilişkin bulgular incelendiğinde, programın bileşenleri hakkında hem olumsuz hem de olumlu algılara sahip oldukları görülmektedir. Kazanımlar hakkındaki olumlu bulgularla başlamak gerekirse, Güneş'in (2009) çalışmasında ulaşıldığı gibi, bu çalışmada da hedeflerin İngilizce dersi öğretim programının genel amaçları ile uyumlu olduğu bulunmuştur. Er (2006) ve Güneş'in (2009) çalışmalarıyla uyumlu olarak, kazanımların birbirleriyle tutarlı oldukları sonucuna varılmıştır. Örmeci (2009), Tekin-Özel (2011) ve Yaman (2010) tarafından yapılan çalışmaların aksine bu çalışmada, Büyükduman (2005), ve Güneş'in (2009) çalışmaları ile benzer şekilde, kazanımların öğrencilerin seviyesine uygun olduğu sonucuna varılmıştır. Ayrıca, kazanımların ulaşılabilir nitelikte olduğu, gözlenebilir ve ölçülebilir nitelikte olduğu, ünite sürelerinde gerçekleştirilebilir nitelikte olduğu, okuma becerisini geliştirebilecek nitelikte olduğu ve okuma becerisini geliştirmek için yeterli sayıda olduğu sonuçlarına varılmıştır.

Öte yandan Örmeci (2009) ve Tekin-Özel (2011) tarafından yapılan çalışmalarda belirtildiği gibi, bu çalışmanın bulguları da bu programın öğrenen özerkliğini geliştiremeyeceğini göstermiştir. Ayrıca, hedeflerin öğrencilerin iletişimsel yeterliklerini geliştiremeyecekleri sonucuna varılmıştır. Bulgular ayrıca kazanımların öğrencilerin dinleme, konuşma ve yazma becerilerini geliştiremeyeceklerini ve bu becerileri geliştirmek için yeterli miktarda olmadıklarını göstermiştir. Bu bulgu, okuma becerileri ile ilgili olan kazanımların ulaşılabilir nitelikteyken, diğer dinleme, konuşma ve yazma becerileri ile ilgili olan kazanımların ulaşılabilecek nitelikte olmadığı sonucuna varan Büyükduman (2005), Güneş (2009), Yaman (2010) ve Yörü’nün (2012) çalışmaları ile aynı doğrultudadır.

Programın içeriğiyle ilgili bulgular, öğretmenlerin olumsuz olanlardan daha çok olumlu algıya sahip olduğunu göstermiştir. Bu çalışmada, içeriğin kazanımlarla uyumlu olmadığını belirten Büyükduman'ın (2005) aksine, Er (2006), Güneş (2009) ve Mersinligil (2002) tarafından yürütülen çalışmaları gibi içeriğin kazanımlarla uyumlu olduğu sonucuna varılmıştır. Ayrıca, Er (2006) ve Güneş'in (2009) çalışmalarıyla uyumlu olarak bu çalışmada içeriğin öğrencilerin ihtiyaç ve ilgi alanlarına uygun olduğunu göstermiştir. Güneş (2009) ve Mersinligil'in (2002) çalışmalarında önerildiği gibi, bu çalışmada, Harman (1999) tarafından yapılan çalışmanın aksine, içeriğin öğrencilerin gelişim düzeylerine uygun olduğu sonucuna varılmıştır. Güneş'in (2009) çalışmasıyla uyumlu olarak, içerik kendi içinde tutarlı bulunmuş 
ve öğrencilerin günlük yaşamlarında kullanabilecekleri bilgileri içerdiği sonucuna varılmıştır. Programın uygulanması için ayrılan sürenin yetersiz olduğu sonucuna varan Büyükduman (2005), Demirtaş ve Erdem (2015), Dinçer (2013), Er (2006), Erdoğan (2005), Erkan (2009), Mersinligil (2002), Ocak, Kızılkaya ve Boyraz (2013), Örmeci (2009), Tekin-Özel (2011), Yaman (2010) ve Yörü'nün (2012) çalışmalarının aksine içeriğin planlanan zamanda bitirilebileceği sonucuna varılmıştır. Bu çalışmanın sonuçlarından bazıları, içeriğin gerçek hayatta uygulanamayacağını ve öğrencilerin yaş ve düzeylerine uygun olmadığını tespit eden Harman'ın (1999) çalışması ile doğrudan tezat teşkil etmektedir. Ayrıca, içeriğin öğrencilerin aktif katılımını sağlayabileceği, hedeflere ulaşıımasını sağlayabileceği ve öğrencilerin okuma becerilerini geliştirebileceği sonucuna varılmıştır. Diğer taraftan, kazanımlara ilişkin bulgular gibi, içeriğin öğrencilerin dinleme, konuşma ve yazma becerilerini geliştiremediği sonucuna varılmıştır.

Programın araç-gereçleri ile ilgili bulgular öğretmenlerin araç-gereçler hakkında olumlu algılara sahip olduğunu göstermiştir. Güneş (2009) tarafından yapılan çalışma gibi bu araştırmada da araçgereçlerin öğrencinin derse aktif olarak katıımını destekleyici nitelikte olduğu, kazanımlara ulaşılmasını destekleyici nitelikte olduğu ve öğrencilerin gelişim düzeyine uygun nitelikte olduğu sonucuna varılmıştır. Bu bağlamda, önerilen araç-gereçler ile ilgili herhangi bir sorun olmadığı ileri sürülebilir.

Etkinliklerle ilgili bulgular, katılımcıların daha çok olumlu algı sahibi oldukları sonucuna varılmıştır. Olumlu yönlerle başlamak gerekirse, Güneş'in (2009) çalışmasında ulaşıldığı gibi etkinliklerin öğrencilerin İngilizceye ilişkin olumlu tutum geliştirmelerine yardımcı olabileceği ve öğrencilerin aktif katılımını artırabileceği sonucuna varılmıştır. Etkinliklerin kazanımlarla tutarlı olmadığı sonucuna varan Er'in (2006) çalışmasının aksine, bu çalışmada tutarlı oldukları sonucuna varılmıştır. Erkan (2009) tarafından yapılan çalışmanın aksine, bu çalışma, Güneş'in (2009) çalışmasına uygun olarak etkinliklerin sınıfta uygulanabilir nitelikte olduğunu göstermiştir. Büyükduman (2005) ve Güneş (2009) tarafından yapılan çalışmalarda bildirildiği üzere bu çalışmada da etkinliklerin öğrenci merkezli oldukları sonucuna varılmıştır. Bunlara ek olarak, öğrencilerin günlük yaşamına paralel oldukları ve öğrencilerin gelişim düzeylerine uygun oldukları sonucuna varılmıştır. Bu olumlu özelliklerin aksine, sonuçlar aynı zamanda etkinliklerin öğrencilerin iletişimsel yeterlik, dinleme, konuşma ve yazma becerilerini geliştiremediğini, sadece öğrencilerin okuma becerilerini geliştirebileceğini göstermiştir.

Son olarak, öğretmenlerin programda önerilen değerlendirme yöntem ve tekniklerine ilişkin algılarına ilişkin sonuçlar, Güneş (2009) tarafından yapılan çalışmada olduğu gibi, yöntem ve tekniklerin uygulanabilir olduklarını ve hedeflere uygun olduğunu göstermiştir. Ayrıca, sonuçlar yöntem ve tekniklerin öğrencilerin gelişim düzeylerini dikkate aldığını, öğrencilerin okuma ve yazma becerilerini ölçmek için kullanılabileceğini gösterirken, öğrencilerin dinleme ve konuşma becerilerini ölçmek için kullanılamayacağını göstermiştir.

Şimdiye kadar İngilizce dersi öğretim programı üzerinde yapılan değerlendirme çalışmaları ile karşılaştırıldığında, bu çalışmanın bulguları, 2012 yılında geliştirilen yeni öğretim programının bileşenleri ile ilgili birçok sorunun çözüldüğünü göstermiştir. Fakat, en önemli sorunların halen mevcut olduğunu da söylemek mümkündür. Bu açıdan en önemli sorun, 1997'den beri geliştirilen diğer programlar gibi, bu programın da öğrencilerin özerkliğini, iletişimsel yeterliliklerini, yazma, dinleme ve konuşma becerilerini geliştiremediğini göstermiştir. Bu program, öğrencilerin yazarak veya konuşarak iletişimsel yeterliliğini geliştirmek üzere tasarlanmış olsa da (MEB, 2013), bu çalışma bu programın öğrencilerin yazma, dinleme ve konuşma becerilerini geliştiremeyeceğini ortaya koymuştur. Bu bağlamda, başarısızlığın programın kendisinden mi yoksa birçok değişkenin etkileyebileceği programın 
uygulanış biçiminden mi kaynaklandığını bulmak için daha fazla araştırmaya ihtiyaç vardır. Ayrıca, benzer çalışmalar Türkiye'nin farklı şehirlerinde yapılarak bulgular karşılaştırılabilir.

\section{Bilgilendirme}

Bu çalışma sorumlu yazar tarafından üretilip Orta Doğu Teknik Üniversitesi'ne teslim edilen "Evaluation of middle school English language curriculum developed in 2012 utilizing Stake's countenance evaluation model" isimli doktora tezinden üretilmiştir.

Bu çalışmanın bir bölümü ayrıca 11-13 Ekim 2018 tarihleri arasında Kars'ta düzenlenen 6. Eğitim Programları ve Öğretim Kongresi'nde sözlü bildiri olarak sunulmuştur. 


\section{References}

Büyükduman, F. İ. (2005). The opinions of elementary school English teachers on the English curriculum for elementary schools. Hacettepe University Journal of Education. 28, 55-64.

Cohen, L., Manion, L. \& Morrison, K. (2007). Research methods in education. London and New York: Taylor and Francis Group.

Collis, B. \& Moonen, J. (1988). Designing an external evaluation of a large-scale software development project. Paper Presented at The International Association for Computing in Education Conference, New Orleans, USA.

Çelik, G. I. (2009). Teacher opinions about 4th classes English programme in primary schools. Unpublished doctoral dissertation, Adnan Menderes University, Aydın, Türkiye.

Demirtaş, Z. \& Erdem, S. (2015). Fifth grade English course curriculum: Comparison of the revised curriculum with the previous curriculum and teachers' views related to the new curriculum. Sakarya University Journal of Education. 5(2), 55-80.

Dinçer, B. (2013). Evaluation of 7th grade English language curriculum according to Stufflebeam's CIPP model. Unpublished master's thesis. Adnan Menderes University, Aydın, Turkey.

Er, K. O. (2006). Evaluation of English curricula in 4th and 5th grade primary schools. Unpublished doctoral dissertation. Ankara University, Ankara, Turkey.

Erdoğan, M., Kayır, Ç. G., Kaplan, H., Aşık-Ünal, Ü. Ö. \& Akbunar, Ş. (2015). Teachers' views on curriculum developed since 2005: A content analysis of the researches between 2005 and 2011. Kastamonu Education Journal. 23(1), 171-196

Erdoğan, V. (2005). An evaluation of the English curriculum implemented at the 4th and 5th grade primary state schools: The views of the teachers and the students. Unpublished master's thesis. Mersin University, Mersin, Turkey.

Erkan, M. A. (2009). Investigation of the matters confronted in application of the new English teaching curriculum for primary schools' 4th and 5th grades (A case study in Gaziantep). Unpublished master's thesis. Gaziantep University, Gaziantep, Turkey.

Ersen-Yanık, A. (2007). A study of English language curriculum implementation in 6th, 7th and 8th grades of public primary schools through teachers' and students' perception. Unpublished doctoral dissertation. Middle East Technical University, Ankara, Turkey.

Fraenkel, J. R, Hyun, H.H. \& Wallen, N.E. (2012). How to design and evaluate research in education (8th Ed.). New York: McGraw Hill

Fritz, W., Möllenberg, A. \& Chen, G. (2002). Measuring intercultural sensitivity in different cultural contexts. Intercultural Communication Studies. 11(2), 1-16.

Güneş, T. (2009). Teachers' Opinions on the English Language Curriculum of the 5th Grade of Primary Education. Unpublished master's thesis. Hacettepe University, Ankara, Turkey.

Harman, K. (1999). Ilköğretim okullarında yabancı dil dersi program uygulamalarında karşılaşılan sorunlar. Unpublished Master's thesis. Harran University, Şanlıurfa, Türkiye.

Koydemir, F. (2001). Erken yaşta yabancı dil öğretiminin bazı değişkenler açısından değerlendirilmesi. Unpublished doctoral dissertation. Dokuz Eylül University, İzmir, Turkey. 
Mersinligil, G. (2002). Evaluation of the English language curriculum for the fourth and fifth grade students in elementary education: A sample of Adana province. Unpublished doctoral dissertation. Çukurova University, Adana, Turkey.

Ministry of National Education. (2013). Ilköğretim kurumları Ingilizce dersi öğretim programı. Ankara: Milli Eğitim Basımevi.

Ocak, G., Kızılkaya, H. \& Boyraz, S. (2013). Evaluation of 6th grade English curriculum in terms of speaking skills and identifying causes of speaking problems students face. International Journal of Academic Research Part B. 5(3), 366-372, doi: 10.7813/2075-4124.2013/5-3/B.55

Oliva, P. F. (1997). Developing the curriculum (4th Ed.). USA: Longman

Ornstein, A. C. \& Hunkins, F. P. (2004). Curriculum: Foundations, principles and issues. Englewood Cliffs, NJ, Prentice Hall.

Ornstein, A. C. \& Hunkins, F. P. (2017). Curriculum: Foundations, principles and issues (7th ed.). USA: Pearson Education Limited.

Örmeci, D. M. (2009). An evaluation of English language curricula implemented at the 4th, 5 th, and 6 th grades in respect of teachers' opinions. Unpublished master's thesis. Trakya University, Edirne, Turkey.

Seçkin, H. (2010). Evaluation of fourth grade English language program. Unpublished doctoral dissertation. Hacettepe University, Ankara, Turkey.

Tekin-Özel, R. (2011). Determination of challenges encountered in the implementation English curricula for primary schools: The sample of Ankara. Unpublished master's thesis. Ankara University, Ankara, Turkey.

Yaman, S. (2010). Assessment of English curriculum for primary schools' 4th and 5th Grades according to teachers' opinions: A case study in Gaziantep. Unpublished master's thesis. Firat University, Elazığ, Turkey.

Yörü, B. (2012). Ilköğretim sekizinci sınıf ingilizce öğretim programına ilişkin öğretmen görüşleri: Eskişehir örneği. Unpublished master's thesis. Osmangazi University, Eskişehir, Turkey. 
Suat Kaya, Ahmet Ok - Uluslararası Eğitim Programları ve Öğretim Çalışmaları Dergisi, 10 (1), 2020, 119-148 